\title{
Between a Rock and a Hard Place: Internal- and external institutional fit of MNE subsidiary political strategy in contexts of institutional upheaval
}

Gerhard Schnyder, Reader in International Management, Loughborough University London, E-mail: G.Schnyder@lboro.ac.uk

Dorottya Sallai (Corresponding author), Assistant Professorial Lecturer, London School of Economics and Political Science (LSE), Department of Management E-mail: d.sallai@lse.ac.uk As accepted at Journal of International Management, December 2019

\begin{abstract}
We investigate how subsidiaries' political capabilities in emerging markets are not just shaped by their home- or host country institutions, but by both simultaneously presenting a dilemma for subsidiaries of multinational enterprises (MNEs) in host countries. Subsidiaries need to develop CPA that simultaneously "fit" parent company requirements and "external fit" requirements in relation to the host environment. Achieving this dual fit is particularly difficult in volatile host contexts, where the value of political capabilities changes rapidly. Subsidiaries face a dilemma because the easily transferable capabilities - that draw on parent resources - lose value due to their decreasing "external fit" with the host country's volatile institutional environment. Conversely, the most valuable relational political capabilities lack "internal fit," as they may not be legitimate in the home environment. To understand how firms deal with this dilemma, we develop a typology of political capabilities that takes into account their transferability/stickiness and their dynamic institutional contingency in the host country. Our study shows that MNEs - even from institutionally very different economies - can successfully transfer political capabilities to develop effective CPA in a volatile political environment. Yet, as political risk becomes discontinuous, this strategy may reach its limits. [196 words]
\end{abstract}

Keywords: nonmarket strategy, subsidiaries, capabilities, CPA, risk 


\section{Introduction}

The 'return of the state' as an economic actor and the rise of more interventionist, autocratic, and state dominated business systems in many developing countries presents Multinational Enterprises (MNEs) from Western countries with particularly severe types of political risk. How do subsidiaries of Western MNEs manage to navigate such challenging institutional environments?

The "return of the state" spans from Brazil's new "developmentalism," to the rise of communist China as a dominant economic power, and the "backsliding" of post-socialist countries in Eastern Europe towards more authoritarian political and economic systems (Sallai \& Schnyder, forthcoming; Greskovits, 2015). A common feature, however, is that the boundaries between the economic and the political domains are becoming increasingly blurred (Boddewyn, 2016; Nölke, 2018; Sallai \& Schnyder, forthcoming; Wood \& Wright, 2015). In such a situation, corporate political activities (CPA) are a particularly important instrument for companies to cope with the changing role of the state (Carney et al., 2016; Danisz et al., 2010; Darendeli \& Hill, 2016; Dieleman \& Boddewyn, 2012; Dieleman \& Sachs, 2008; Iankova \& Katz, 2003; Luo, 2007; Nell et al., 2015; Zhang et al., 2016). Yet, little is known about how foreign subsidiaries develop such local nonmarket strategies (Carney et al., 2016; Jean \& Tan, 2019; White et al., 2018a).

Recent studies have shown that foreign subsidiaries' host country political and market strategies are to an important extent determined by their home country institutional environment (White et al., 2018a; White et al., 2018b; Yu \& Lee, 2019; Konara \& Shirodkar, 2018). The "fit paradigm" (Brouthers et al., 2000; Fortwengel, 2017a; Luo \& Park, 2001; Zajac et al., 2000) suggests that subsidiary's performance outcomes may be affected by the fit between an MNE parent's capabilities and the foreign subsidiary's strategic practices abroad (White et al., 2018a). 
While acknowledging the need for "internal fit" between the organizational capabilities of the MNE and the subsidiary; in terms of "external fit" - i.e. institutional pressure - these studies either focus on home- (White et al. 2018a) or host country institutions (Hillman \& Wan, 2005), few acknowledge the simultaneous influence of both (Edwards et al., 2019; Mingo et al., 2018). Yet, MNEs are embedded in multiple institutional contexts. Their political strategies are therefore simultaneously influenced by home- and host country institutions (Kostova \& Zaheer, 1999; Kostova \& Roth, 2002). According to Zajac et al. (2001) the multi-dimensional nature of "strategic fit" creates a potential tension" for the firm when seeking a fit between its strategy and its environmental context and a fit between its "strategy and its unique competencies" (Zajac et al., 2001: 430). Applied to the MNE and acknowledging that political capabilities are partly shaped by the institutional environment (Whitley, 2007), this implies that effective CPA requires the subsidiary to simultaneously strive for "internal fit" with institutionally-structured parent capabilities and "external fit" with the host country environment (cf. Fortwengel, 2017a). This raises two further issues that the extant literature does not explicitly address: First, the "fit paradigm" is based on the assumption that political capabilities are transferable across borders (Carney et al., 2016; Fernández-Méndez et al., 2018; Holbourn \& Zelner, 2010). Yet, the need for host country external fit suggests that this may not be the case of all political capabilities (cf. Hill \& Wan, 2005). Indeed, it has been argued that some political capabilities are "developed based on the firm's experience in a specific country and so may not be portable across geographies" (Doh et al., 2012: 31; also Bonardi et al., 2006; Fernández-Méndez et al., 2018). Therefore, the transfer of institutionally structured political capabilities can be expected to be difficult.

Second, existing studies on political capability transfer and fit - while acknowledging the temporal nature of capability development in the home context (Carney et al., 2016; Dieleman \& Widjaja, 2019; White et al., 2018a) - do not sufficiently acknowledge the 
implications of instable institutional environments in the host country. Indeed, the very nature of "unstable" or "weak" institutional environments implies that institutional pressures are in constant flux (Chen et al., 2017; Young et al., 2008). The literature has shown that in volatile environments political capabilities may change in value dramatically (Darendeli \& Hill, 2016; Henisz \& Delios, 2004; Leuz \& Oberholzer-Gee, 2006; Oetzel \& Oh, 2014; Siegel, 2007; Sun et al., 2010). Therefore, it is crucial to pay more attention to the dynamic nature of fit between political institutions and nonmarket practices (cf. Zajac et al., 2001). We seek to address both issues by developing a new model (summarized and compared to existing concepts in figure 1).

We contribute to the "fit paradigm" by proposing an enhanced typology of political capabilities that connects the "institutional structuring" (Whitley, 2007) of political capabilities to their transferability across borders on the one hand, and their changing value in terms of their fit with the host environment on the other hand. We seek to answer two research questions: (1) How does the effectiveness and hence value of different types of foreign subsidiary political capabilities change during radical institutional change? (2) How do foreign subsidiaries leverage different types of political capabilities through transfer or local development to achieve "external fit" of their CPA with radically changing host country institutions?

Our empirical context is Hungary under Viktor Orbán’s governments since 2010. During this period, firms operating in Hungary have experienced a phase of radical institutional change that can be referred to as "institutional backsliding," which is part of a wider phenomenon of "the return of the state" (Bremmer, 2008). In the post-socialist context, it describes a departure from the Western-influenced reform path to a democratic market economy, towards more authoritarian forms of economic and political governance (Sallai \& 
Schnyder, forthcoming). As such, Hungary constitutes a politically extremely uncertain environment, where the rules of the game are kept in constant flux.

We contribute to the resource-based approach to CPA (Frynas et al., 2006; Hillman \& Hitt, 1999; Lawton et al., 2013; Oliver \& Holzinger, 2008), by enhancing existing typologies that do not take into account the question of transferability - or its opposite "stickiness ${ }^{1}$, " and the contingent value of political capabilities in fast-changing institutional environments. We also contribute to the recent literature that found that the internal "strategic fit" between subsidiary nonmarket strategy, parent company capabilities, and home country institutions are key to the success of nonmarket strategies (White et al., 2018a). Our study extends this view and suggests that an external fit between subsidiary CPA and the host country's institutional environment is equally important to understand effective CPA. Our study thus makes an important contribution to the understudied question of how institutional differences across countries shape MNE political activities (Doh et al., 2012: 27; Liedong et al., 2015; White et al., 2018a). We also make an important empirical contribution by gathering unique primary data about CPA through semi-structured interviews with top level managers in an emerging market economy with a very volatile political environment. Such studies remain scarce, which has hampered theorization (Lux et al., 2011; White et al., 2018a).

\footnotetext{
${ }^{1}$ Defined as the difficulty with which organizational practices or routines can be transferred across borders (Jensen and Szulanski, 2004; Szulanski, 1996).
} 


\section{Literature and Theory}

CPA tends to co-evolve with its institutional environment (Doh et al., 2012; Feinberg et al., 2015; Hillman \& Wan, 2005; Lux et al., 2011), because institutions play an important role in structuring political capabilities (Bonardi et al, 2006; Holbourn \& Zelner, 2010; White et al., 2018a; generally Whitley, 2007). In the case of MNEs and their subsidiaries, this implies that each subsidiary is exposed to two institutional environments - the home and the host country (Kostova \& Roth, 2002). For MNEs the engagement in CPA offers a mechanism to overcome disadvantages that surface when competing with local firms on foreign markets (Kline \& Brown, 2019). The "institutional development and resource endowment of the home country provide the foundation for firms to develop resources" that they can use in their host environments (Estrin et al., 2018:524), and affect their internationalisaton strategies (Estrin et al., 2017; Ren et al., 2019; Yan et al., 2018), while the host country's environment might affect how MNEs learn to adapt to international markets (Tsui-Auch \& Chow, 2019).

Existing CPA studies have focused on how "institutional duality" forces companies to achieve internal legitimacy - i.e. strategic fit between subsidiary and parent political strategy -, while acknowledging that host institutions create a need for external fit (Hillman \& Wan, 2005). Yet, they do not explicitly acknowledge home-country institutional pressures. Others investigate how home country institutions shape parent capabilities with which subsidiary political strategies need to strategically fit (White et al., 2018a; Yu \& Lee, 2019) (cf. figure 1). Curiously, the existing literature has not considered that the transference of home country political capabilities to a host setting meets a dual challenge; namely to achieve simultaneously "internal fit" with (institutionally-shaped) parent political capabilities and "external fit" with the host country institutional environment. An effective political strategy will need to combine transferred and locally developed capabilities in a way that both 
satisfies "internal fit" with the parent company and "external fit" with the host environment (cf. Fortwengel, 2017a). To account for this, a theory of political capabilities needs to include more systematically the determinants of transferability of political capabilities across borders and the changing "value" - in terms of external fit - of political capabilities in the changing host setting. 
Figure 1: Two models of institutional determination of subsidiary CPA in emerging markets Home country external fit only (based on White et al., 2018a)

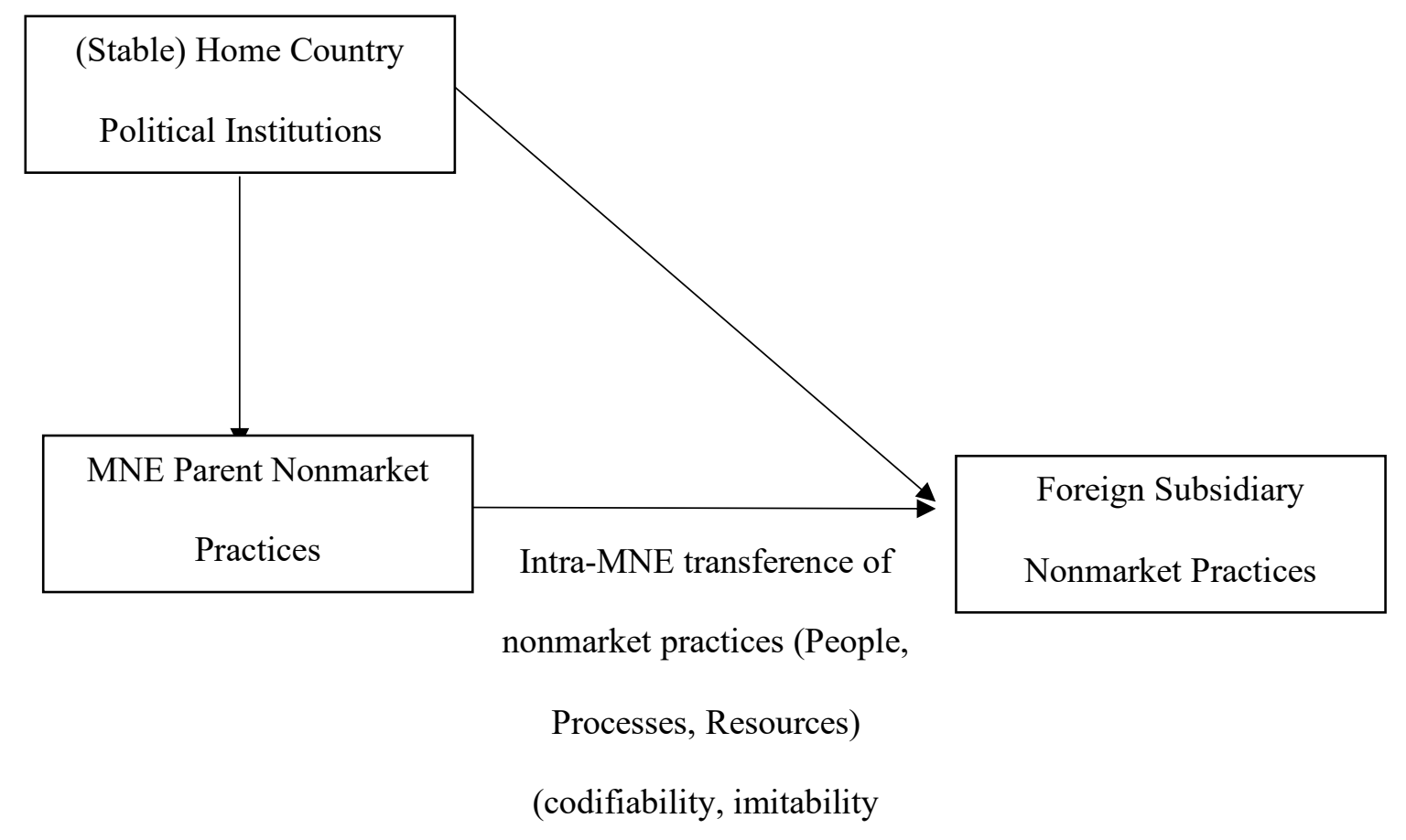

Simultaneous home- and host-country external fit

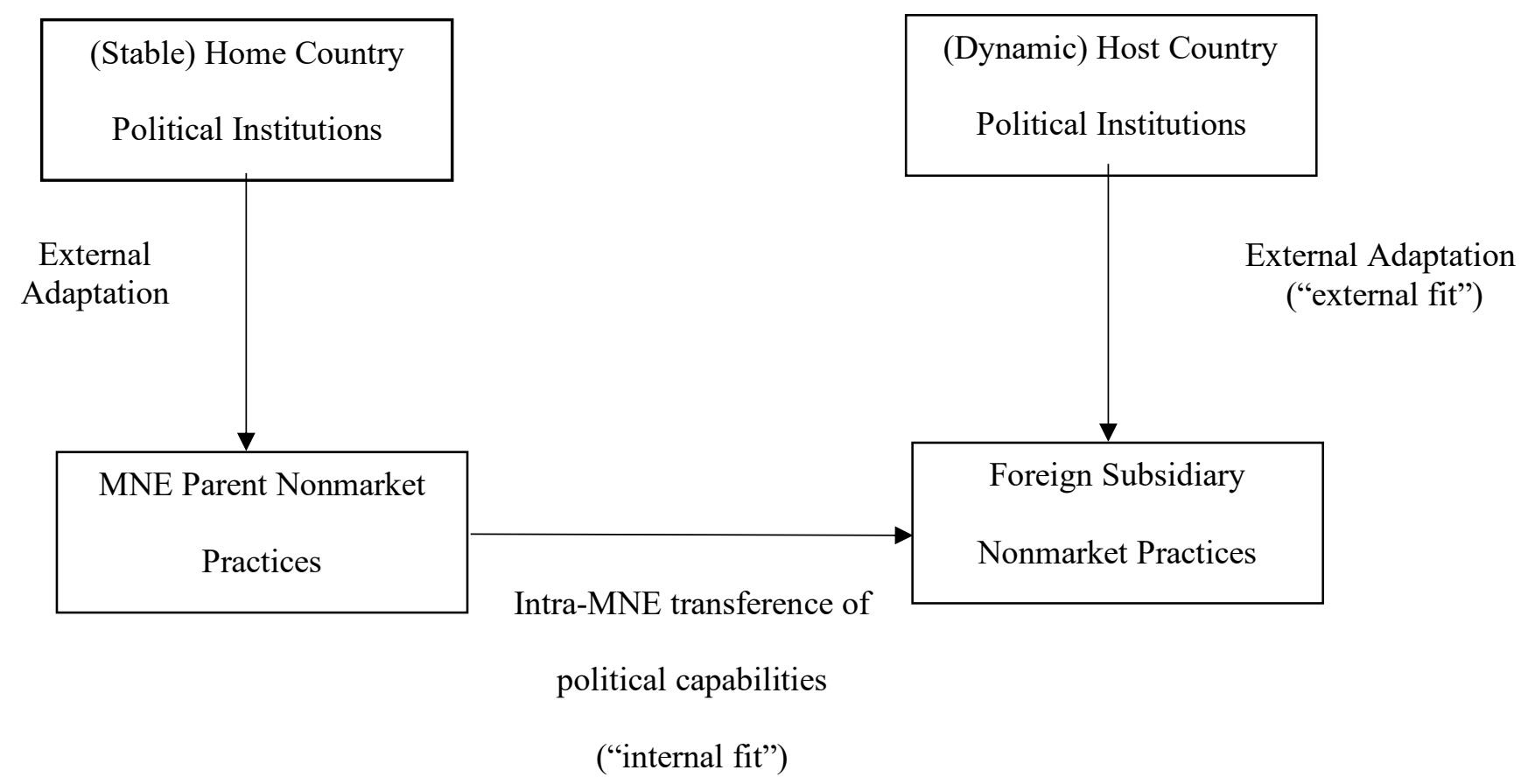




\subsection{The fit paradigm: Internal- and external fit of political capabilities}

The "fit paradigm" (Brouthers et al., 2000; White et al., 2018a) - often implicitly comprises two analytically distinct claims: first that companies need to seek a fit between their strategies and their capabilities; second, that the strategy - and the capabilities it is based on - also needs to match the companies' external environment (Fortwengel, 2017a). This constitutes what Zajac et al. (2001) call the multi-dimensional nature of the "strategic fit" concept.

White et al.'s (2018a) useful attempt to apply the "fit paradigm" to political strategies focuses on the "internal fit" of subsidiary strategies with institutionally-shaped parent company capabilities, but neglects the "external fit" between subsidiary political strategy and host institutional environment (similarly Yu \& Lee, 2019). Hillman and Wan (2005: 328), on the other hand, hint at the "external fit" between host country context and subsidiary political strategy and hint at the difference between political strategies that rely on easily transferable capabilities and others relying on "sticky" ones. Yet, they do not theorize this relationship. To fill this gap in the literature, two questions need to be answered: What types of political capabilities do different institutional contexts require? What determines their transferability across national boundaries? We tackle them in turn.

\subsection{Institutional contexts and fitting capabilities}

The notion that political capabilities and strategies differ across institutional settings is well-established. The most basic distinction here is between rule-governed and relationshipbased institutional systems. "Rule-based governance systems rely on public rules - formal laws and government regulations - to encourage and facilitate economic exchange" (Judge, 2012: 411). They support generalized arm's-length exchange via markets based on a strong legal system of public ordering (cf. Chen \& Deakin, 2015; Whitley, 2007; Peng, 2003). 
Relationship-based governance systems rely on private ordering through "informal relationships and norms of reciprocity - to encourage and facilitate economic exchanges" (Judge, 2012: 411; also Carney et al., 2016; Peng 2003). In emerging markets, some firms establish political connections to compensate for institutional weaknesses or voids (Deng et al., 2018).

To be sure, there is a great variety of national institutional systems within each one of these categories (Fainshmidt et al., 2016; Whitley, 2007; Witt et al., 2017; Witt \& Redding, 2013). Still, generally speaking, in developing contexts long-term, personal relationships have greater importance in organizing economic transactions than in advanced economies, where enforceable legal rules allow for impersonal "arms'-length" transactions to take place (Chen \& Deakin, 2015; Hall \& Soskice, 2001; North, 1990; Weimer \& Pape 1999; Whitley, 2007). Thus, in many Asian countries, "personalistic ties" at the individual level are more important than impersonal, institutionalized relationships (cf. Redding, 1990; Fukuyama, 1995; Hamilton, 1996; Hitt et al., 2002). Thus, Witt and Redding (2013: 279) state that it is a "wellestablished finding in the literature that individuals in Asian societies tend to build stronger interpersonal networks, both inside the family and with friends, than their Western counterparts and tend to leverage them for business." Beyond specific regions, relationship-based ordering occurs more often in volatile and uncertain environments (Peng, 2003; Young et al., 2008).

Relationships are important in advanced economies as well. In particular, Hall and Soskice (2001) argued that firms in countries like Germany and Japan rely more on nonmarket relationships than their Anglo-Saxon counterparts. However, compared to relationships in countries with weaker formal institutions (Murillo \& Levitsky, 2009), in advanced countries relationships are relatively more transparent and less exclusionary (Young et al., 2002). 
We can further distinguish volatile and uncertain political environments where risks are continuous - e.g. corruption (Cuervo-Cazurra, 2008) - and hence relatively predictable for firms, from environments, where political risk becomes "discontinuous" and hence unpredictable, e.g. revolutions, coups, and civil wars (Oh \& Oetzel, 2017; Oetzel \& Milikan, 2017; Getz \& Oetzel, 2009). Extremely volatile political environments, where state intervention becomes completely arbitrary - like during phases of "institutional backsliding" - come close to situations of "discontinuous risk."

These different institutional contexts favor different types of CPA. In rule-governed systems, where transactional market exchanges are the norm, CPA is "largely about legal, firm-level engagement with institutionalized political actors and structures" (Lawton et al., 2013: 87). CPA is a professionalized, transactional, issue-driven activity, that follows fairly transparent and clear "rules of the game" (Beyers et al., 2008; Griffin and Dunn, 2004; McGrath, 2005; Thomson and John, 2007; Van Schendelen, 2012; Voinea \& van Kranenburg, 2018) and which is mostly viewed as an "essential, legitimate and distinguishable activity, which supplements business activity" (Hadjikhani and Ghauri, 2006: 391).

Formalized, or "structured" CPA that prevails in rule-governed systems does not exist in relationship-based systems (Lawton et al., 2013: 92) and we know little about how MNEs develop nonmarket capabilities in institutionally 'fragile' environments (Mbalyoherea \& Lawton, 2018). In these contexts there is no "public affairs culture" (Harsányi \& Schmidt, 2012) and CPA remains a taboo (Sallai, 2013). Instead, CPA is dominated by informal personal contacts between politicians, public officials, and managers. Informal relationshipbased types of CPA matter in developed countries too (King \& Pearce 2010; McDonnell \& Werner 2016); but they tend to be less important, more transparent, and less particularistic than in developing ones (Sun et al., 2015). 
Therefore, the institutional context may make certain CPA types ineffective. Indeed, the political capabilities that Western researchers associated with political strategies, such as "incentive systems that accelerate the speed and quality with which public policy demands are implemented" (Oliver \& Holzinger, 2008: 508), may be utterly inadequate to deal with volatile environments (Darendeli \& Hill, 2016; Oh \& Oetzel, 2017). Radically changing political environments - e.g. due to wars and rebellions - dramatically change the effectiveness of certain political resources (such as political ties) and require specific political strategies based on locally-developed political capabilities for firms to survive (Darendeli \& Hill, 2016; Getz \& Oetzel, 2009; Oetzel \& Oh, 2014; Oh \& Oetzel, 2017; White et al., 2018a).

Conversely, relationship-based strategies and the related resources and capabilities may lose their legitimacy, effectiveness, and hence value when the institutional environment moves from a relationship-based towards a rule-based or arm's length system (Sun et al., 2010). Certain types of CPA may simply not be considered legitimate in certain environments and may hence be counterproductive (Darendeli \& Hill, 2016; Sallai, 2013). This goes beyond the question of whether the company engaging in CPA is perceived as an outsider and hence illegitimate (Hillman \& Wan, 2005), but concerns the very nature of the capabilities themselves that firms mobilize.

From the "fit perspective," this hints at a tension facing Western subsidiaries active in volatile environments: while they need to strive for "internal fit" of their political strategies with their home country's institutionally-shaped capabilities, the same capabilities may become increasingly ineffective in dealing with a host country institutional environment that moves away from formal institutions and becomes less predictable. Conversely, those that are most effective at achieving "external fit" in the host context, are the least suitable to achieve "internal fit," e.g. because particularistic personal political capabilities are less legitimate in 
the home environment. Simultaneously, the capabilities needed to deal with the volatile environment may not be readily available to subsidiaries, as they are strongly locallyembedded and may take a long time for firms to develop (Carney et al., 2016; Darendeli \& Hill, 2016; Fernández-Méndez et al., 2018). We call this the "transferability-value dilemma" - whereby the most readily available capabilities through transfer are the least valuable in the volatile context. Conversely, the most valuable ones are both more difficult for subsidiaries to acquire and reduce "internal fit." In the next section, we argue that the resolution of this dilemma will depend on the transferability of different types of political capabilities.

\subsection{The transferability of political capabilities}

The "fit paradigm" as applied to the CPA literature is based on a strong assumption regarding the transfer of capabilities and practices from headquarters to subsidiaries. Indeed, "internal fit" essentially implies that subsidiaries develop strategies that draw on parent company capabilities, which in turn necessitates transference (Hillman \& Wan, 2005). The MNE's ability to leverage intangible knowledge resources and reconfigure assets across national borders constitutes possibly its most important dynamic capability (Dunning and Lundan, 2010; Jensen \& Szulanski, 2004). This also applies to CPA: MNEs can transfer political capabilities developed in the home country (Carney et al., 2016; Fernández-Méndez et al., 2018; Holbourn \& Zelner, 2010) or in other host countries (Delios \& Henisz, 2003) to a new host environment. Carney et al. (2016) show that certain capabilities to deal with authoritarian governments can be transferred across similar institutional environments. Similarly, White et al. (2018a: 13) implicitly consider intra-MNE transference of non-market practices through "people, processes, resources" to be straightforward.

Transference of political capabilities may reduce the time an organization needs to adapt to a new political environment, because transfer of existing capabilities can be expected 
to be quicker than locally developing new ones. It may hence constitute a key capacity to develop effective political strategies in volatile environments (Oliver \& Holzinger, 2008).

Yet, the literature on transfer of practices (Edwards et al., 1999; Edwards et al., 2015; Ferner et al., 2012; Gamble, 2010; Kostova, 1999; Kostova et al., 2008) and in particular on the "stickiness" of practices and capabilities (Szulanski, 1996; Jensen \& Szulanski, 2004) has shown that leveraging capabilities across borders is far from a straightforward process. Not all political capabilities may be transferable across borders (Bonardi et al., 2006; Doh et al., 2012; Hillman \& Wan, 2005; Oh \& Oetzel, 2017), or they may lose some of their value (Jean \& Tan, 2019). Yet, the determinants of transferability of political capabilities have not systematically been studied. Here we draw on the practice transfer literature to cover this gap.

The transfer literature considers that the key factor affecting political capabilities' transferability or "stickiness" is the ability to codify the underlying knowledge. Thus, Dunning and Lundan (2010: 1227) consider that "transfer requires that specific practices can be isolated and articulated into routines that can become 'best practices'." If a capability is codifiable, "knowledge-based conduits" of transfer - such as specialist information systems can be put in place to facilitate transfer within the MNE (Edwards et al., 2015). Yet, by far not all political capabilities are codifiable. Rather, many of them are related to informal practices that are based on very personal and tacit knowledge. Generally, Hillman and Wan (2005: 328) argue that financial incentive political strategy - lobbying through campaign contributions etc. - can be more easily transferred across borders than information- and constituency-building strategies, because the former are based on tangible assets (such as money) while the latter rely on relational "political skills." Fernández-Méndez et al. (2018) argue that political ties created by a former politician on a company's board do not constitute a valuable political resource for the firm abroad, because her contacts will be locationspecific. Yet, the political knowledge resulting from the politician's involvement may allow 
the firm to develop political capabilities that are useful abroad (Fernández-Méndez et al., 2018).

Oh and Oetzel (2017) find that the capability acquired by an MNE subsidiary to manage violent conflict may be too country-specific to be valuable in another country. They argue that discontinuous risks, i.e. "those that are episodic and difficult to anticipate" (Oh \& Oetzel, 2017: 727) may require more in-depth, context-specific knowledge, which can be expected to make them less valuable in other contexts (also Oh \& Oetzel, 2011; Perkins, 2014). Conversely, "continuous risks" - e.g. corruption - may be less country-specific and capabilities developed to deal with such risks in one country can be expected to be valuable to deal with similar risks in other countries (Oh \& Oetzel, 2017: 727; Perkins, 2014; Qi et al., 2018; Zyglidopoulos et al., 2019).

Capabilities that cannot easily be codified, may still be transferable to some extent, notably through "people-based conduits", e.g. the use of expats to transfer tacit knowledge (Edwards et al., 2015; Rui et al., 2017). Yet, here the specificity of political capabilities is important: while production or sales related capabilities (Luo \& Park, 2001), as well as capabilities related to internal functions such as HRM (Edwards et al., 2015) may involve employees at different levels of the organization, the nature of political strategies is such that they often concern the higher-echelons of the corporate hierarchy (Sallai, 2013). This limits their transferability through people-based conduits, as the pool of holders of the required tacit knowledge is narrower.

Based on these insights, we now turn to revisiting existing typologies of political capabilities to enhance them with the dimensions of stickiness/transferability.

\subsection{Integrating transferability in typologies of political capabilities}

Different typologies of political strategies exist, which assume different types of resources and capabilities underlying each strategy. Hillman and Hitt (1999: 825) distinguish 
information-, financial incentive-, and constituency-building- strategies. The information strategy is associated with formal lobbying or commissioning and delivering technical reports (Hillman and Hitt, 1999: Table 1). The financial incentive strategy is associated with contributions to politicians and parties, while the constituency building strategy relies on grassroot mobilization of employees, suppliers, or customers.

Oliver and Holzinger (2008) suggest another typology based on the distinction between a "compliance approach" and an "influence approach" to CPA. The former focuses on a firm's internal capabilities and aims at adapting the organisation to its political environment by reacting to regulatory changes (the reactive strategy) or anticipating such changes (the anticipatory strategy). The influence approach, on the other hand, uses a firms' external capabilities and aims at shaping the institutional environment by trying to protect the status quo from unwanted political change (the defensive strategy), or by actively promoting institutional change that benefits the firm (the pro-active strategy) (Oliver \& Holzinger, 2008: 507). Internal capabilities are organizational routines that ensure compliance with laws and allow firms to anticipate policy change with a view to gain a first mover advantage by complying early (Oliver \& Holzinger, 2008: 509). External capabilities include the deployment of social capital stemming from ties with policymakers and lobbying to prevent changes that would undermine the company's competitive advantage (Oliver \& Holzinger, 2008: 510).

These two classical typologies of political capabilities have two important shortcomings when applied to MNE CPA in emerging markets. Namely, they neglect the institutional structuring and fit of political capabilities (Whitley, 2007) and their transferability across borders (Carney et al., 2016).

Regarding institutional structuring, Hillman and Hitt (1999) suggest that the three strategies and related capabilities can be deployed across a variety of contexts. Indeed, the 
only institutional determinant of political strategy choice considered is the degree of pluralism/corporatism that prevails in a country (Hillman \& Hitt, 1999: 828). Yet, the distinction between pluralist and corporatist institutions may be important in Western countries but may be irrelevant in countries where the certainty and stability of institutions themselves is in question. In such contexts, the stronger local embeddedness of political capabilities (Carney et al., 2016; Oh \& Oetzel, 2017; Darendeli \& Hill, 2016), will affect the transferability of capabilities. We propose a new typology of political capabilities that takes into account their transferability and is summarized in table 1. 
Table 1: Transferability and Formality/Codification of political capabilities

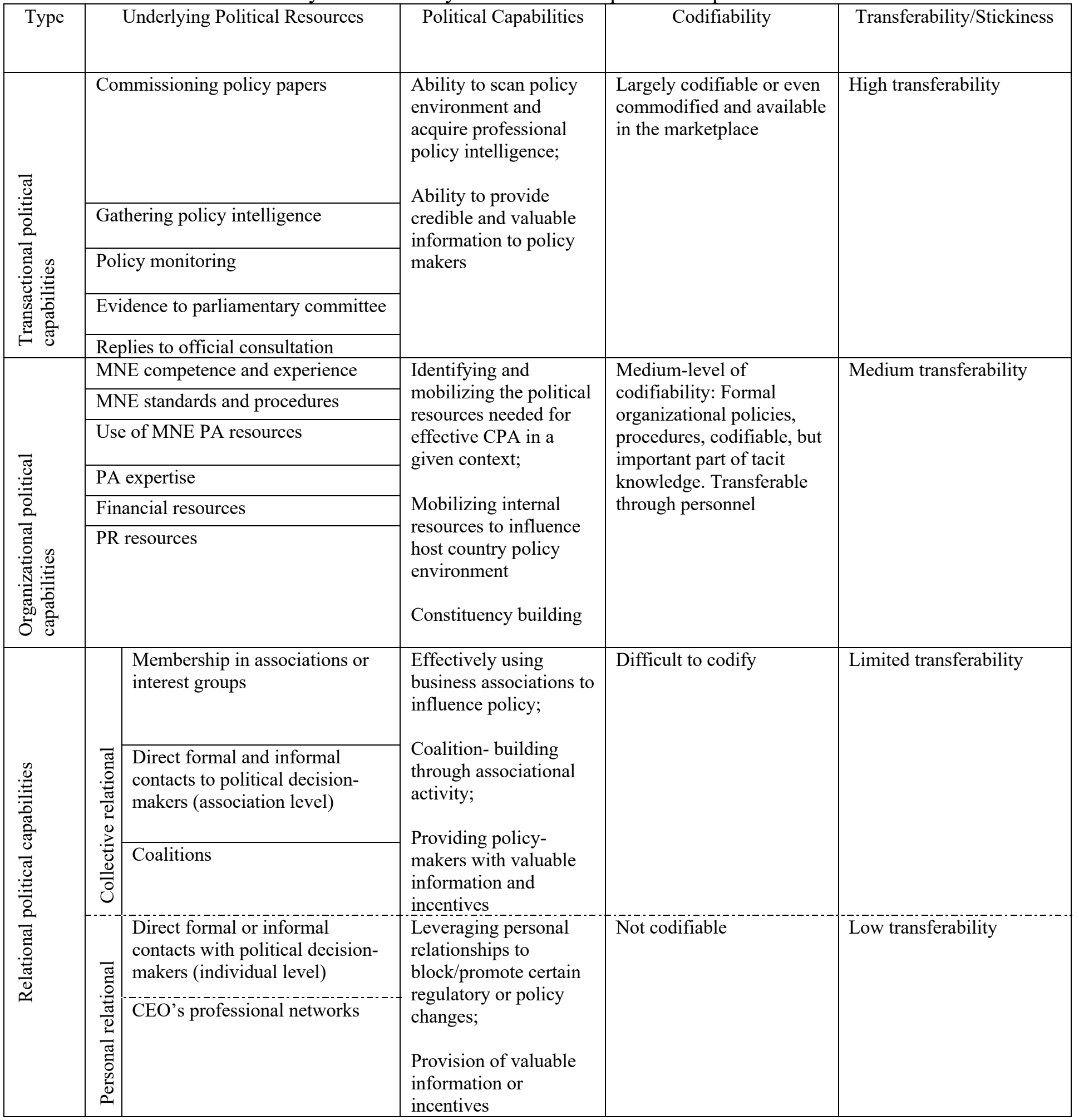

Like existing typologies, we distinguish internal- or "organizational-" from external political capabilities. Organizational political capabilities are those that are readily available 
within the organization (e.g. internal expertise) (Jensen \& Szulanski 2004). They draw on organizational resources such as internal policy analysis, public affairs departments etc. While organizational capabilities may be codified (e.g. through internal regulations and formal policies - Teece et al., 1997), they may also be based on tacit, non-codifiable knowledge. Organizational capabilities are by definition, contingent on the organizational institutional environment in the sense that organizations will develop them in reaction to the institutional environment in which they originate (Child et al., 2012; Whitley, 2007). Therefore, we would expect organizational capabilities of MNEs from developed countries (DMNEs) and their subsidiaries to differ from domestic firms (DFs) from relationship-based systems.

We further distinguish two types of external capabilities, namely capabilities deployed based on market transactions, which we call transactional capabilities, and capabilities deployed via social networks, which we call relational capabilities. Capabilities in the transactional category broadly correspond with capabilities required for what Hillman and Hitt (1999) call the transactional CPA approach and include capabilities linked to “information strategy," such as formal lobbying (Hillman \& Hitt 1999; see also Voinea \& van Kranenburg, 2018). They are characterized by their reliance on formal market exchanges based on codified knowledge-assets. Thus, official exchange of expertise and information e.g. through formal channels such as responses to consultation procedures, fall into this category. Similarly, formal lobbying efforts such as a company's ability to acquire political intelligence from a third party - e.g. a policy research or consultancy firm - are transactional political capabilities. Generally, transactional political capabilities, like other market-based (intangible) assets, can be acquired in the marketplace, and tend to be codifiable and commodifiable, which decreases their stickiness (Barnard, 2010). As such, they are related to 
tangible resources - including financial ones - used by firms in the financial political strategy (Hillman \& Wan, 2005).

In contrast, relational capabilities, which correspond with capabilities used in Hillman and Hitt's (1999) relational approach to CPA, include formal and informal contacts and ties with political decision-makers that are based on non-codified and often implicit knowledge. Following Zhang et al. (2016), who distinguish collective CPA from personal CPA, we further distinguish relational political capabilities according to whether they exist at the individual level or at the organizational level. Thus, memberships in industry associations or interest groups are collective relational political resources, while a CEO's personal network is classified as a personal political resource (cf. Zhang et al. 2016). In practice, the difference may not always be clear-cut. Thus, formal and informal meetings with public officials can be classified either as a collective capability (e.g. managers as representatives of the company meeting with public officials) or a personal one (a top manager meeting with public officials based on friendship-, family-, or other personal ties).

Transferable capabilities exist in all three categories e.g. money is an easily transferable organizational capability, membership in a business association a relatively easily transferable collective relational one (cf. Bonardi, 2011). However, we would expect the first two categories in this typology to be more readily transferable than capabilities of the relational type, because relational ones are usually based on tacit knowledge in the form of personal relational skills and hence not codifiable (Hillman \& Wan, 2005). We would also expect collective relational capabilities to have some degree of transferability, while personal relational ones have the lowest transferability, because they are tied to specific individuals rather than being impersonal like organizational relationships. Therefore, they can only be transferred through upper-echelon personal conduits (cf. Edwards et al., 2015).

\subsection{Value and institutional fit of political capabilities}


The value of a political capability can be defined in two ways: first, its availability to the firm and second its usefulness in dealing with the institutional environment - i.e. its "external fit". Regarding availability, the political capabilities literature generally follows the "resource-based view" in considering that the resources a political strategy generates are "valuable, inimitable, and imperfectly mobile across firms" (Oliver \& Holzinger, 2008: 512). Tacit knowledge reduces the imitability and hence transferability of routines across firms and increases thus their value (Kotabe et al., 2011). Yet, transferability of political resources and capabilities within firms may be key to MNC competitiveness in fast changing environments by making important capabilities available. Here codifiability and hence imitability, which increases intra-MNE transferability, may increase rather than decrease the value of a political capability. Indeed, Bonardi (2011) argues that the key resource-based view tenant of inimitability of resources has only limited relevance for the value of political capabilities. Thus, the most important political resource - money spent on lobbying and campaign contributions - is not hard to imitate (Bonardi, 2011: 248). In terms of the "fit paradigm" transferable political capabilities are valuable, because they allow it to achieve "internal fit." Yet, while transferability may positively affect political capabilities in terms of availability, it may have a contrary effect on the second determinant of value, namely “external fit." Oh and Oetzel (2017) find that knowledge-assets transferred through the MNE tend to be more superficial and less adapted to the local context than locally developed ones. More generally, the more rule-governed a system is, the more transactional political capabilities will be effective and hence valuable, because market-based political resources are available and market-based CPA is legitimate (Lawton et al., 2013; Hillman \& Wan, 2005). Conversely, the more relationship-based it is, the more personal- and organizational political ties can be expected to be important for effective CPA (Boddewyn, 2016; Sun et al., 2010). Within relationship-based systems, the more discontinuous political risks there are, the more 
context-specific political capabilities will need to be (Oh \& Oetzel, 2017). Since personal relational political capabilities are the most context-specific, they are hence most legitimate and valuable in achieving "external fit" in such situations.

Organizational political capabilities are less easy to classify in terms of "external fit," because they have by definition co-evolved with a firm's institutional environment and are hence a reflection of its experience (Oh \& Oetzel, 2017). Therefore, their fit with the dichotomy of relationship- vs. rule-governed institutional environments is contingent on the company's history and previous experience.

We expect the interaction between transferability and external fit to determine the effectiveness of MNE subsidiary CPA. The more relationship-based a system (especially when risk is discontinuous), the more transferable transactional capabilities lose value and the more sticky relational ones become important (cf Table 2).

Table 2: Institutional fit and value of political capabilities in a host-country setting

\begin{tabular}{|c|c|c|c|}
\hline $\begin{array}{c}\text { Political } \\
\text { capabilities }\end{array}$ & Rule-based & $\begin{array}{l}\text { Relationship-based (continuous } \\
\text { risk) }\end{array}$ & $\begin{array}{l}\text { Relationship-based } \\
\text { (discontinuous risk) }\end{array}$ \\
\hline 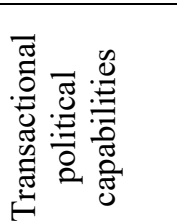 & $\begin{array}{l}\text { Legitimate and valuable } \\
\text { and }\end{array}$ & Less legitimate and less valuable & Limited value \\
\hline 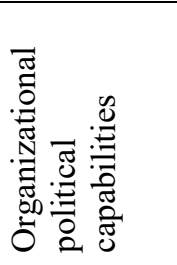 & $\begin{array}{l}\text { Potentially valuable, but } \\
\text { contingent on past } \\
\text { experiences }\end{array}$ & $\begin{array}{l}\text { Potentially valuable, but contingent } \\
\text { on past experiences }\end{array}$ & $\begin{array}{l}\text { Potentially } \\
\text { valuable, but highly } \\
\text { contingent on past } \\
\text { experiences }\end{array}$ \\
\hline 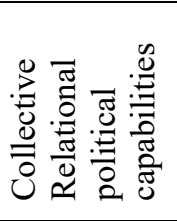 & Valuable and legitimate & Crucial & $\begin{array}{l}\text { Less legitimate and } \\
\text { less valuable }\end{array}$ \\
\hline 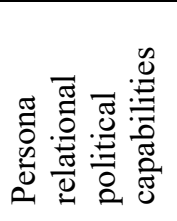 & $\begin{array}{l}\text { Less legitimate, but } \\
\text { potentially valuable }\end{array}$ & Crucial & Crucial \\
\hline
\end{tabular}




\section{Methods}

\subsection{Empirical context: Institutional backsliding in a post-socialist country}

To explore how Western subsidiaries adapt their CPA to an increasingly volatile political environment, we focus on the case of Hungary in a period of radical institutional change. We focus on DMNEs and assume that, despite cross-national differences, they all share a fundamentally rule-governed home environment, while Hungary as host environment has increasingly moved from a relatively rule-governed to a relationship-based one, and political risk has increasingly become discontinuous.

Indeed, by the mid-2000s, Hungary had advanced to one of the most consolidated democracies among post-socialist countries (EBRD, 2005). Since the 2010 elections, - when Viktor Orbán's conservative party Fidesz acquired a two-thirds majority in the parliament however, Hungary's “democracy score" has declined, bringing it closer to some of the less developed semi-consolidated democracies, like Romania and Bulgaria (Walker and Habdank-Kołaczkowska, 2012: 6). This recent trend, shared by other post-socialist countries, has been termed "backsliding," which describes the move from the initial pro-market reform path towards a more authoritarian political system and a more state-controlled economy (Greskovits, 2015; Sedelmeier, 2014). Increased state intervention during "backsliding" is evidenced by nationalizations (and in some cases subsequent re-privatizations) (Szanyi, 2016; Bałtowski \& Kozarzewski, 2016), and the increasing level of corporate appropriations, such as "forced buy-outs" (FBOs), where individuals close to the governing elite put pressure on owners of companies to relinquish ownership (Sallai \& Schnyder, forthcoming). In Hungary, backsliding also involves mechanisms such as arbitrary changes to the tax code disadvantaging foreign firms and legal changes aimed at restructuring entire industries. This type of business system has been labelled "authoritarian capitalism" (Sallai \& Schnyder, forthcoming) and is characterized by a return to increasingly relationship- rather than rule- 
based types of economic transacting. While this aspect only constitutes one of several dimensions along which Hungary is distinct from more advanced economies, it does capture one critical dimension. In this study, we focus on this dimension, because it is the key aspect influencing CPA.

\subsection{Case selection and research design}

Our study is based on a longitudinal case study, which is suitable for investigating the temporal nature of the phenomenon under investigation, namely the development of political strategies using transferred and locally developed political capabilities.

\subsubsection{Sample}

Our sample is divided into DMNEs and DFs. It is based on purposive sampling through predetermined selection criteria, as it is often the case in qualitative research (Miles and Huberman, 1994). Ideally, the sample should be constituted in a way that holds as many variables as possible constant (Darendeli and Hill, 2016). Yet, due to the small size of the Hungarian economy and the sensitive nature of the topic at hand, which led to a low willingness of firms to participate in the study, our MNE sample comes from different home countries and different industries. Nevertheless, they form a single group in terms of the relative similarity of the home countries, which are all highly developed western economies. This choice is justified by our interest in the ability of MNEs from stable, formal rulegoverned contexts to transfer political capabilities to uncertain, relationship-based systems. The second group are domestic Hungarian firms also distributed across a variety of sectors. The Hungarian firms constitute a control group in the sense that it is composed of domestic firms, which do not have the possibility of transferring capabilities.

While a self-selection bias cannot be completely excluded, we are confident that our results are not affected by our sampling method. Indeed, the sectoral composition of the sample is diverse: Overall, our sample contains firms from eleven different industries. The 
largest industries in our sample were information and communication technologies (ICT) and the construction sector (table 3).

\subsection{Data collection and analysis}

Our data stem from multiple rounds of data collection and a variety of sources: indepth interviews with business leaders and experts from the context of the case, as well as documentary analysis of news and various reports over seven years. Data collection and data analysis was carried out in parallel. We went back and forth in an iterative process to interpret our material and reflect on how it advanced our understanding of the constructs used in the literature. Overlaps in data collection and analysis are beneficial, since this approach "reveals helpful adjustments to data collection" (Eisenhardt, 1989: 535).

To obtain multiple perspectives and a more complete and nuanced view of firms' political capabilities, we sought a range of opinions as recommended for this type of research (Perry, 1998: 798). We carried out 56 semi-structured interviews (see table 3): 43 with business leaders working at MNE subsidiaries and domestic firms and a further 13 with experts in the context of the case. The MNE subsidiaries in the sample originated from the US (6), France (4), Germany (3), United Kingdom (1), Switzerland (1), Denmark (1), Italy (1), and the Netherlands (1). We tended to interview only one person per company, because political activity in Hungary is virtually always limited to the very top of the managerial hierarchy (Sallai, 2013). Therefore, in most cases the CEO, the Managing Director or the public affairs director were deemed to possess the necessary information to answer our questions. Due to the longitudinal nature of the study, we have interviewed in several cases the same respondents both in the early years of the Orbán regime in 2011-2013 as well as recently in 2015-17. We carried out 32 interviews in the first period (2011-2013) and another 24 in the second (20152017). This allowed us to obtain informed views on the changes over time.

Table 3: Number of interviews by industry, title of interviewee and date 


\begin{tabular}{|c|c|c|}
\hline Company industry (number of interviews) & Position of interviewee & Date of interview \\
\hline \multirow{6}{*}{ 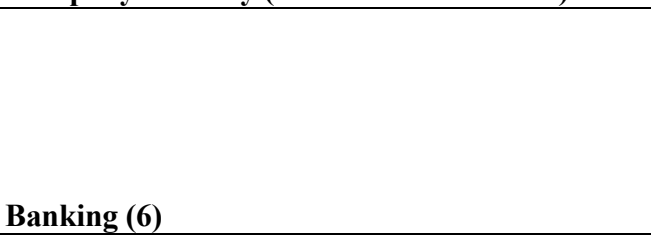 } & CEO (Subsidiary) & 15.07 .2016 \\
\hline & CEO (Local) & 13.07 .2016 \\
\hline & CEO (Subsidiary) & 24.01 .2012 \\
\hline & Vice-CEO (Local) & 07.03 .2012 \\
\hline & CEO (Subsidiary) & 26.01 .2012 \\
\hline & Vice-CEO (Subsidiary) & 07.03 .2012 \\
\hline \multirow[b]{7}{*}{ Construction (7) } & Director (Local) & 15.07 .2016 \\
\hline & CEO (Subsidiary) & 10.04 .2015 \\
\hline & CEO (Subsidiary) & 11.01 .2012 \\
\hline & CEO (Local) & 07.03 .2012 \\
\hline & CEO (Local) & 15.11 .2011 \\
\hline & Director (Local) & 20.06 .2011 \\
\hline & CEO (Local) & 22.06 .2011 \\
\hline \multirow[b]{6}{*}{ Energy (6) } & PA Director (Subsidiary) & 10.04 .2015 \\
\hline & PA Director (Subsidiary) & 06.05 .2013 \\
\hline & Director (Local) & 04.08 .2011 \\
\hline & Head of Strategy (Local) & 02.07 .2011 \\
\hline & PA Director (Subsidiary) & 06.09 .2011 \\
\hline & Director (Local) & 31.08 .2011 \\
\hline \multirow[b]{7}{*}{ ICT (7) } & CEO (Local) & 12.04 .2017 \\
\hline & Director (Subsidiary) & 16.02 .2017 \\
\hline & CEO (Local) & 16.07 .2016 \\
\hline & $\begin{array}{l}\text { Director of Government Affairs } \\
\text { (Subsidiary) }\end{array}$ & 26.01.2012 \\
\hline & Former CEO (Subsidiary) & 05.09 .2011 \\
\hline & CEO (Local) & 16.06 .2011 \\
\hline & $\begin{array}{l}\text { Former Director of Government } \\
\text { Affairs (Subsidiary) }\end{array}$ & 01.09 .2011 \\
\hline \multirow[b]{5}{*}{ Manufacturing (5) } & Director (Subsidiary) & 31.05 .2017 \\
\hline & CEO (Subsidiary) & 23.08 .2016 \\
\hline & CEO (Subsidiary) & 23.08 .2016 \\
\hline & CEO (Local) & 15.12 .2011 \\
\hline & CEO (Local) & 20.06 .2011 \\
\hline \multirow[b]{2}{*}{ Telecommunication (2) } & CEO (Subsidiary) & 15.08 .2016 \\
\hline & Vice-CEO (Subsidiary) & 09.08 .2015 \\
\hline \multirow[b]{4}{*}{ Retail (4) } & Director (Subsidiary) & 15.07 .2016 \\
\hline & Director (Subsidiary) & 13.08 .2016 \\
\hline & Director (Subsidiary) & 16.04 .2012 \\
\hline & General Managing Director (Local) & 08.05 .2011 \\
\hline \multirow[b]{2}{*}{ Wholesale (2) } & CEO (Local) & 13.02 .2017 \\
\hline & CEO (Local) & 30.03 .2012 \\
\hline \multirow{4}{*}{$\begin{array}{l}\text { All other sectors: tobacco, tourism, advertising, } \\
\text { beverages (4) }\end{array}$} & Director (Subsidiary) & 16.02 .2017 \\
\hline & Managing Director (Subsidiary) & 16.08 .2016 \\
\hline & Managing Director (Local) & 16.02 .2013 \\
\hline & CEO (Local) & 30.03 .2012 \\
\hline \multirow[b]{9}{*}{ Experts from the context of the case (13) } & Secretary General & 17.02 .2017 \\
\hline & Managing Director & 13.04 .2017 \\
\hline & Secretary General & 29.05 .2017 \\
\hline & Secretary General & 16.08 .2016 \\
\hline & Public affair Director & 13.08.2016 \\
\hline & Managing Director & 23.01 .2012 \\
\hline & Secretary General & 11.01 .2012 \\
\hline & Managing Director & 22.11 .2011 \\
\hline & Executive Director & 16.11 .2011 \\
\hline
\end{tabular}




\begin{tabular}{|c|c|c|}
\hline & Director & 09.11 .2011 \\
\hline & Managing Director & 28.09 .2011 \\
\hline & Journalist & 31.05 .2017 \\
\hline & Political adviser & 31.08 .2011 \\
\hline Total number of interviews (56) & $\begin{array}{l}2011(18), 2012(12), 2013(2), 2015 \\
(3), 2016(12), 2017(9)\end{array}$ & 56 \\
\hline \multirow[b]{2}{*}{ Total number of interviews at firms (43) } & MNE subsidiaries & 23 \\
\hline & Domestic firms & 20 \\
\hline
\end{tabular}

The semi-structured interview technique provided a single framework for the different interviews (Flynn et al., 1990), but also gave flexibility to ask questions in relation to previously not identified issues that arose from the interviewee's responses (Bryman, 2004).

Interviews were conducted in English and in Hungarian. Interviews were conducted and recorded by one of the researchers at the respondents' offices and were later transcribed. Each interview lasted for 50-90 minutes. Interviews in Hungarian were translated by one of the authors. Most interviews were carried out in Budapest.

In addition to the interviews, we used secondary sources to increase our confidence about the reliability of the interview responses. We analyzed over 70 pieces of printed and online newspaper articles and reports from corporate websites, journalistic sources, and publications by reputable NGOs such as Transparency International. Due to the lack of scholarly research on these topics in Hungary, such sources are often the only information available and are more reliable than official government sources.

After the transcription of the interviews we used the NVivo software to perform an open coding of the data according to recurring themes. This first step was followed by a process of axial coding. We used both open and axial coding, because we seek to "refine and differentiate concepts that are already available" (Böhm, 2004: 271). Indeed, we used the theoretical concepts of stickiness, transferability, value, transactional-, organizational-, and (personal and collective) relational political capabilities as our categories. In the post-coding stage, we followed Miles and Huberman's (1994) framework - namely the process of reducing data, displaying data, and drawing and verifying conclusions. 
The goal of the analytical process was to find evidence indicating the stickiness or transferability of different capabilities and how they are acquired or developed by different firms to develop effective CPA. Next, we selected the most relevant quotes that would illustrate the different capabilities of each type. We then used our other data to better understand how these capabilities were developed and used and whether these capabilities were transferable or not (explanation building).

In the last step of data analysis, we used our data to understand how the value of different political capabilities has changed as a result of the changes in the institutional environment and how the availability of capabilities changed as a consequence.

During the second round of interviews, we started to refine emerging themes and asked respondents to comment directly on specific aspects of our emerging findings. The use of this type of external check mitigated the potential biases of individual respondents and enabled us to obtain richer insights from the aggregate data (Santos \& Eisenhardt, 2009).

Throughout the overlapping data collection and analysis, we sought to critically engage with the interview data and situate them within the broader context of informants' interests and social position. Through this process of triangulation and iteration, we sought to decrease possible bias and interpret the data in a more nuanced manner (Yin, 2003).

\section{Findings}

Our empirical case allows us to explore how foreign subsidiaries seek to develop effective CPA strategies to cope with radically changing institutional environments, while achieving both internal and external fit.

Our interviews show that before 2010, Hungary was transitioning towards a more rulegoverned system. In this period, subsidiaries relied on all three types of capabilities (transferable transactional and organizational ones, as well as stickier relational ones), while DFs predominantly relied on relational capabilities. Indeed, even during the early Orbán years, 
when the government started to restrict access to these formal channels, MNEs were able to leverage transferred transactional and organizational capabilities to engage with the formal policy-making process.. Virtually all respondents stressed the difference in the availability of transactional and organizational capabilities for MNEs and their absence in DFs. Consequently, DFs were largely excluded from the formal policy-making process. One respondent stated:

"When the government - reluctantly - sends documents for review or debate, it tries to prevent opinions by sending the document last night, requiring feedback by the following morning. Companies are normally not prepared to submit any feedback to these. But multinationals are prepared to give feedback even in 24 hours." (Respondent, Subsidiary11)

Top managers of subsidiaries performed active policy monitoring, e.g. they wanted to know who is dealing with a given policy in the different ministries, because transferable organizational capabilities allowed them to prepare lobbying documents that could be channeled into the legislative process early on (Respondent, Subsidiary11).

Some DFs too undertook certain types of transactional political strategies - e.g. systematic legislative monitoring (e.g. Respondent, Local16). However, these strategies appear less effective than MNE subsidiaries' activities due to the relative lack of organizational resources compared to subsidiaries (e.g. Respondent, Local9; Respondent, Local8). One respondent stated:

"Hungarian lobbying is more a surface type lobbying, not carrying hundreds of pages of professional arguments" (Respondent, Local5).

Therefore, during the pre-Orbán and early-Orbán phase, MNE subsidiaries achieved a comparative advantage by transferring transactional and organizational political capabilities from the home country. These capabilities both achieved "internal-" and "external fit" with an increasingly rule-governed environment. 
Yet, even in this period, the institutional context in Hungary was still more relationship-based than the Western MNEs' home context. This implied that to achieve "external fit," relational political capabilities were important for MNEs too. The quote from Subsidiary12 illustrates this:

"Networks are important in Germany and everywhere in the West as well, but here they are dominant. Business goes through networks." (Respondent at Subsidiary12)

Our interviews show that in this respect, when entering the country, subsidiaries were at a certain disadvantage compared to DFs, because they lacked local relational resources to deal with the relational host context. These relational capabilities could not be easily transferred from the home environment (e.g. Respondent, Subsidiary14). Local firms, on the other hand, were often well-connected to the state bureaucracy. As the respondent from one local firm simply put it: "[We] have to have good contacts with the state. We know everybody" (Respondent, Local10; similarly, respondent Local6).

However, MNEs managed to overcome this disadvantage by locally developing relational political capabilities. Interestingly, they did so by leveraging their transactional and organizational political capabilities. One important way in which MNE subsidiaries developed collective relational capabilities is by hiring well-connected local staffeffectively using the MNE's organizational capability to pay good salaries to attract wellconnected individuals. Thus, interviewees at local subsidiaries stated:

"The best is to employ somebody, or a company who have done this [political activity] already in this country." (Respondent, Subsidiary10)

“...we employed more Hungarian managers to develop business relationships but also political relationships”. (Respondent, Subsidiary4)

This strategy also applied to subsidiaries' CEOs who played a more important role in managing political activities than in the home country (Sallai, 2013). CEOs were often 
involved in direct political negotiations with policymakers and represent a subsidiary-related resource that contributes to the local political strategy through personal relational capabilities.

In short, during the transition towards a rule-governed system and in the early years of Orban's government, foreign subsidiaries were able to develop successful political strategies by leveraging transactional and organizational political capabilities in an increasingly rulegoverned environment, while local firms had not developed transactional and organizational capabilities to deal with such an environment. This suggests that the transfer of transactional and organizational political capabilities and leveraging them to locally develop relational ones allowed subsidiaries to achieve internal- as well as external fit and provide them with an advantage compared to DFs. Table 4 summarizes the key findings regarding the availability of different types of political capabilities to MNEs and DFs and provides representative quotes from the interviews. 
Table 4: Availability of political capabilities to subsidiaries and domestic firms

\begin{tabular}{|c|c|c|c|}
\hline & & \multicolumn{2}{|c|}{ Representative Quotes } \\
\hline Type of capability & Examples & MNEs & Domestic Firms \\
\hline $\begin{array}{l}\text { Transactional } \\
\text { capabilities }\end{array}$ & $\begin{array}{l}\text { Political strategy } \\
\text { Policy papers } \\
\text { Coalition building } \\
\text { Intelligence } \\
\text { Policy monitoring } \\
\text { Policy replies }\end{array}$ & $\begin{array}{l}\text { "Hungarian companies do it [lobbying] } \\
\text { on their own, or they go through an } \\
\text { association and plus they engage in } \\
\text { their own ways as well, by finessing... } \\
\text { At [multinationals,] it [lobbying] is } \\
\text { coordinated. And in the associations } \\
\text { our professionals prepare very serious } \\
\text { documents and all the lobbyists of the } \\
\text { industry say the same. We argue for } \\
\text { industrial interests." (Respondent, } \\
\text { Subsidiary11) }\end{array}$ & $\begin{array}{l}\text { "Our interest representation was } \\
\text { not very effective before either, } \\
\text { but today even less. There is } \\
\text { [only] the media and our } \\
\text { [informal] discussions with the } \\
\text { decision-makers." (Respondent, } \\
\text { Local 9) }\end{array}$ \\
\hline $\begin{array}{l}\text { Organizational } \\
\text { capabilities }\end{array}$ & $\begin{array}{l}\text { MNE competence } \\
\text { and experience } \\
\text { MNE standards and } \\
\text { procedures } \\
\text { Use of of MNE PA } \\
\text { resources } \\
\text { PA expertise }\end{array}$ & $\begin{array}{l}\text { "There is huge experience and } \\
\text { background internally at these } \\
\text { companies [MNE subsidiaries]. They } \\
\text { have a professional for this } \\
\text { [lobbying/CPA] and international } \\
\text { support. They collect international } \\
\text { benchmarks; they hire consultants to } \\
\text { write policy papers, and even } \\
\text { legislative proposals." (Respondent, } \\
\text { Subsidiary11) }\end{array}$ & $\begin{array}{l}\text { "Hungarian companies do not } \\
\text { have political departments, not } \\
\text { even a person, who does it." } \\
\text { (Respondent, Local 9) } \\
\text { Also: Respondent, Local 01; } \\
\text { Respondent, Local 12 }\end{array}$ \\
\hline $\begin{array}{l}\text { Relational } \\
\text { capabilities }\end{array}$ & & & \\
\hline $\begin{array}{l}\text { Collective } \\
\text { relational }\end{array}$ & $\begin{array}{l}\text { Membership in } \\
\text { associations or } \\
\text { interest groups } \\
\text { Direct formal and } \\
\text { informal networks to } \\
\text { political decision- } \\
\text { makers (association } \\
\text { level) }\end{array}$ & $\begin{array}{l}\text { Collective } \\
\text { "We are members of an association } \\
{[\ldots] \text { and they represent what we do, }} \\
\text { and they prepare policy } \\
\text { recommendations with us and these are } \\
\text { channeled to the decision makers." } \\
\text { (Respondent, Subsidiary18) } \\
\text { "We are active in the [...] Chamber of } \\
\text { Commerce" (Respondent, Subsidiary2) }\end{array}$ & $\begin{array}{l}\text { "Wollective } \\
\text { "We can do lobbying through the } \\
\text { engineering association that } \\
\text { represents individuals, but we are } \\
\text { also members of consultant } \\
\text { engineers, the Hungarian chamber } \\
\text { of commerce. We believe it is } \\
\text { very important to be represented } \\
\text { on events. Everything depends on } \\
\text { personal contacts, you never } \\
\text { know. "(Respondent, Local 1) } \\
\text { Also: Respondent, Local 16; } \\
\text { Respondent, Respondent, Local 5, } \\
\text { 10; Respondent, Local 6) }\end{array}$ \\
\hline $\begin{array}{l}\text { Personal } \\
\text { relational }\end{array}$ & $\begin{array}{l}\text { Direct formal or } \\
\text { informal contacts } \\
\text { with political } \\
\text { decision-makers } \\
\text { (individual level) } \\
\text { CEO's professional } \\
\text { networks }\end{array}$ & $\begin{array}{l}\text { Personal } \\
\text { "I know a lot of decision-makers. I } \\
\text { organize meetings between leading } \\
\text { decision-makers like ministers and } \\
\text { state secretaries and the management of } \\
\text { my company. "(Respondent, } \\
\text { Subsidiary11) }\end{array}$ & $\begin{array}{l}\text { Personal } \\
\text { "Therefore, we have to have good } \\
\text { contacts with the state. We know } \\
\text { everybody. "(Respondent, Local } \\
\text { 10) Also Respondent, Local } 6\end{array}$ \\
\hline
\end{tabular}


As the Orbán government consolidated its power, the regime used various tools and mechanisms to the country's political and economic system into a more authoritarian and particularistic relationship-based one characterized by discontinuous political risk (Sallai \& Schnyder, 2019). As institutional pressures to engage in relationship-based exchanges became stronger, the "external fit" between political capabilities transferred from the subsidiaries' parent and the host environment decreased, reducing thus the value of these capabilities. Thus, CEOs of subsidiaries were losing some of their influence, notably due to the increasing nationalism of the government:

"First they [MNEs] need to find a good CEO, it is rare that a foreigner is allowed in this." (Respondent, Subsidiary10)

Yet, faced with discontinuous political risk, even the strategy of hiring local CEOs to establish political ties with the government has become less efficient due to the constantly and arbitrarily changing formal and informal rules:

"[T]he problem [with hiring well-connected locals] is that they knew the old mechanisms. The new mechanisms under this government are different."

(Respondent, Subsidiary10)

"We miss the corporate network, and this is a really big trouble as the corporate network can really influence government affairs. Our European leadership does not understand the importance of this. To understand this [local networks] you have to live here. It is a competitive disadvantage that we do not have a strong Hungarian CEO who socialized in this world." (Respondent, Subsidiary7)

Simultaneously, subsidiaries' ability to engage in the new types of CPA required coping with the increasingly relationship-based and authoritarian regime is limited by headquarter standards, creating a tension between internal- and external fit. Our interviews clearly show that during backsliding, money has once again become an important political resource 
(Respondent, Local7). While money is one of the most liquid and hence transferrable political resource (Bonardi, 2011), in the specific context of backsliding, MNE subsidiaries lack the capability of mobilizing it (at least overtly), due to home-country/parent pressures. Our interviews suggest that, subsidiaries' leeway in engaging in bribery to get access to the political arena appears more limited than domestic firms', because MNEs tend to have stronger anti-corruption standards and are potentially exposed to stronger scrutiny of homecountry media and anti-corruption activists than domestic firms. In other words, the increasing misfit between the home institutional environment and the host environment, decreases the value of this political capability due to the lack of legitimacy of certain practices in the home country context.

One respondent referred to this dilemma:

"We have very strong ethical compliance standards. It is natural, however sometimes it is not easy to adhere to them." (Respondent, Subsidiary7)

Sometimes dilemmas do not only relate to bribery or direct monetary support, but nonethical or anti-competitive practices, such as the use of "state-recommended" suppliers, without a competitive selection process:

"The other issue, where the state is dominant is the appearance of the statepreferred suppliers in the system. Companies try to work together with these suppliers based on their [the company's] own values or against those." (Respondent, Subsidiary7)

In other words, often firms are required to source from suppliers that are recommended by public officials or middlemen. This may go against internal standards of selecting suppliers; forcing managers to choose between their parent company's standards and local pressures. Other, indirect forms of monetary transfers have also emerged, which are less obviously contradicting Western subsidiaries' home country institutional pressures and can provide an 
alternative channel to bribes. The most usual ones are supporting specific charities selected by people close to the governing elite and contracting a consultancy firm specialized in public affairs, which then gains access to the political arena, without the subsidiary knowing how. One CEO described the way in which the consultancies treat the companies' requests for access as 'smoke and mirrors' (Respondent of Subsidiary5).

Moreover, despite of the increasing personalization and informalization of statebusiness relationships during institutional backsliding, the government has also established new - more closely state-controlled - formal ways for companies to engage with the authorities. The most important one is the so-called "strategic partnership" between firms and the government. As one respondent explained:

"The big change came with the signature of the strategic partnership with the government. [...] What these agreements can really help [with], is to build highest-level relationships. If I say that I have an issue they will arrange a meeting on the highest level. 2-3 times a year our European leader can meet the Minister and we get reassuring messages. We use this a lot more recently." (Respondent, Subsidiary7)

Strategic partnerships thus provide a way for subsidiaries to acquire (collective) relational political resources (e.g. Subsidiary15) without having to resort to practices that are incompatible with home-country institutional pressures and parent company standards.

In summary, our interviews show that up to the election of Orbán as PM in 2010, the increasingly rule-governed institutional environment allowed subsidiaries to leverage organizational and transactional political capabilities, which were available to them due to their being part of an MNE. Since 2010 however, the institutional environment in Hungary has once again become much less favorable to rule-based transactions, which has decreased the value of transactional and also of collective relational capabilities in a context of 
discontinuous political risk. The most effective political resources that allow firms to have their voice heard in the political arena are particularistic-, personal relationships with actors close to the governing elite, the use of politically 'recommended' suppliers, contractors and consultancies, the support of certain politically connected charities or outright bribery.

Particularistic relationships are not transferable and MNEs may hence lose some of their competitive advantage compared to local companies. Our interviews show indeed that although, most subsidiaries seem to be aware of the "availability" of the necessary capabilities in the new environment, not all of them are willing to acquire them. This suggests that the need for internal fit constitutes an important roadblock to transferability and effective CPA. Yet, we also find that MNEs have found ways to develop alternative capabilities e.g. engagement with consultancy firms or the integration of recommended suppliers, which are considered legitimate in both home- and host country.

Our findings allow us to further extend the theory of political capabilities. They show that subsidiaries not only combine different types of capabilities - some transferred, others locally developed - but actively use transferable ones to develop relational ones. In other words, transferred political capabilities provide subsidiaries with a competitive advantage not only by neatly fitting the host country institutional context (external fit), but by providing subsidiaries with the means to develop locally fitting political capabilities. For instance, MNE subsidiaries "buy in" personal relational political capabilities by appointing well-connected individuals from the host country. Different types of capabilities can hence be combined to develop an effective CPA strategy. We therefore propose:

Proposition 1: During the transition towards a more rule-governed system, MNE subsidiaries from advanced economies can leverage transferable transactional-, and organizational political capabilities to develop "sticky" relational ones in the host country. 
This finding also suggests that by leveraging transferable political capabilities to create "sticky" relational ones, subsidiaries gain a competitive advantage over domestic firms. Indeed, while DFs initially possess superior relational capabilities, they lag behind MNE subsidiaries regarding organizational and transactional capabilities, which becomes a disadvantage during processes of transition, where transactional capabilities become more valuable. We therefore propose:

Proposition 2: DFs from emerging countries - due to resource constraints and the domestic orientation- lack transactional- and organizational political capabilities, which puts them at a competitive disadvantage compared to MNE subsidiaries during the process of transition towards a more rule-governed system.

However, DMNE's successful leveraging of the different types of capabilities will depend on the institutional pressures emanating from the host country's political context. During backsliding, pressures increase towards relationship-based personal exchanges and political risk becomes increasingly unpredictable. As a result, the value of (personal) relational capabilities increases, while that of transactional ones decreases. Thus, when asked about the phase of backsliding, one respondent argued:

"There are some [name of sector] leaders, who keep more permanent relationships with these institutions, and we can see that legislation is more beneficial for those who have better networks." (Respondent, Subsidiary4)

Other respondents confirm that not only are relationships becoming more important once again during backsliding, but also they are more personal and have to be with a narrower circle of people close to the governing elite to be effective. In this phase, successful political activity requires personal access to a small elite, which may need to be obtained by means that are incompatible with home country pressures. The political capabilities required for 
access to the increasingly autocratic state are not (openly) supported by the headquarters. This implies that the relational capabilities required in this phase are less and less compatible with the home-country's institutional context; therefore, achieving "internal fit" becomes more difficult for subsidiaries. We propose:

Proposition 3: In the context of backsliding, DMNEs' ability to develop effective CPA strategies will decrease, because external fit in the host country will increasingly depend on personal relational capabilities that are incompatible with home-country legitimacy requirements (internal fit).

Conversely, DFs do not face the same constraints as DMNEs due to their domestic orientation. We propose:

Proposition 4: In the context of backsliding, DFs ability to develop effective CPA increases compared to DMNEs due to the absence of contradicting legitimacy requirements constraining the use of personal relational capabilities.

Figure 2 (see below) illustrates how our propositions expand existing theory, focusing on the dynamic process of capability transfer. While current literature acknowledges the home country institutional fit requirement of political capabilities (White et al., 2018a), we argue that in the dynamic transition process the value and the transferability of political capabilities changes depending on their internal- and external fit in relation to the home and the host country's institutional pressures. 
Figure 2: The dynamic model of capability transfer in different phases of post-socialist transition
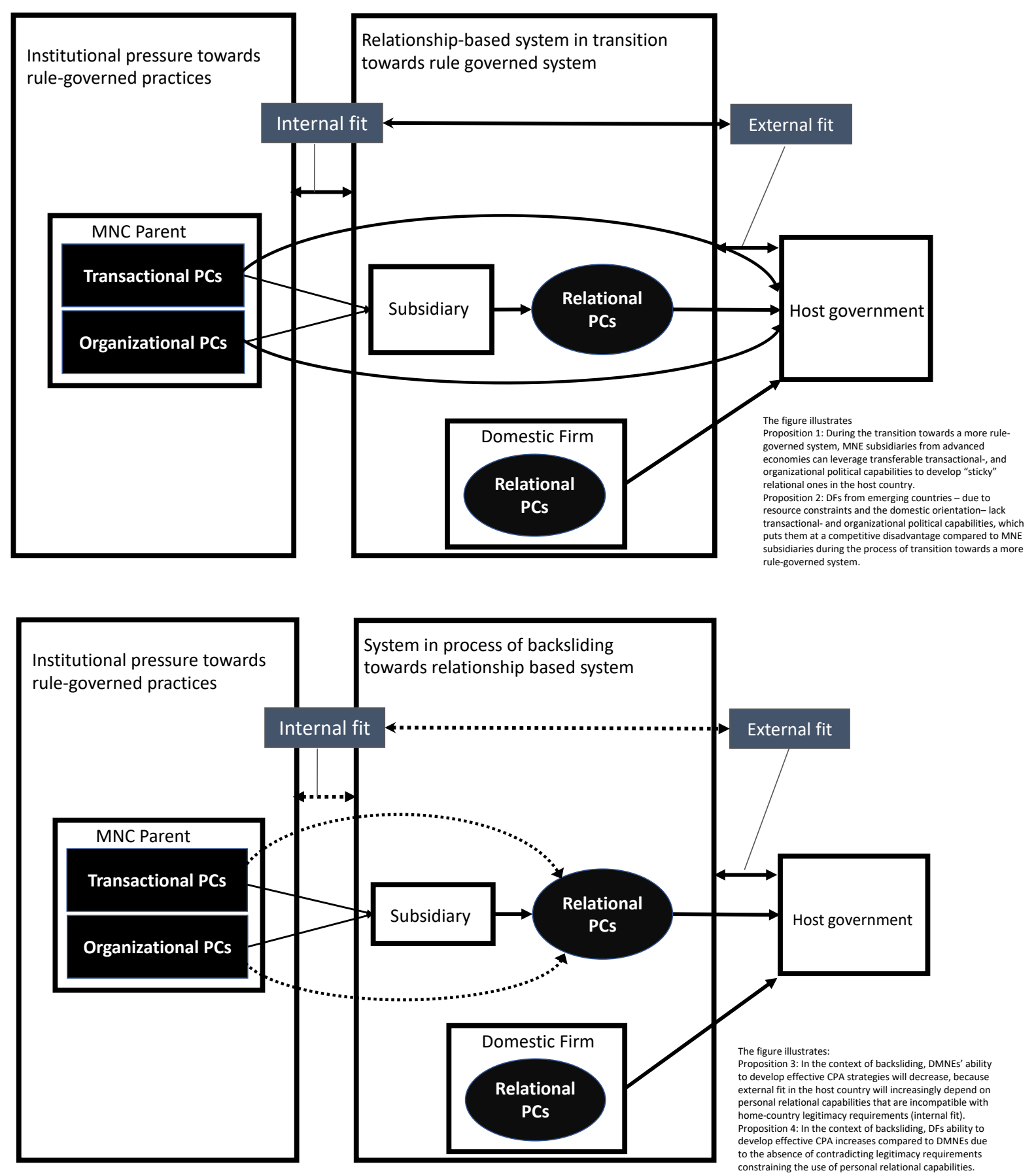


\section{Discussion and Conclusion}

By considering how simultaneous home- and host country institutional pressures create a dual challenge for subsidiaries to achieve both internal- and external fit, our study makes an important contribution to the understudied question of how institutional differences across countries shape MNE political activities (Doh et al., 2012: 27; Fortwengel, 2017b; Liedong et al., 2015; Mingo et al., 2018). We argue that further developing the "fit paradigm" (White et al., 2018a) as applied to CPA, requires us to incorporate two dimensions into existing typologies of political capabilities, which are mostly implicit and unsystematic in the extant literature. These are the varying transferability/stickiness of political capabilities and the contingency of their value in volatile political environments ("external fit").

We focus on the case where the home environment is stable and rule-governed, while the host country environment is relationship-based and in the process of a shift towards increasingly discontinuous political risk. We find that subsidiaries do not merely adapt to relationship-based contexts by engaging in relational strategies (Luo and Zhao, 2013), but design a localized "combined" political strategy that leverages transferred political capabilities with locally developed ones. This finding is in line with previous literature on transference of practices (Gamble, 2010). This is because not all political capabilities are easily transferrable from home to host country and because some that are transferrable may not be valuable in certain host environments. In such a situation, subsidiaries leverage parent organizational- and transactional capabilities to locally develop relational ones. As such, our study complements previous research that found that emerging market MNEs can transfer capabilities they developed to cope with a politicized economy in their home system to relatively similar host contexts (Carney et al., 2016). This has been termed the "adversity advantage" of MNEs from home-countries with weak formal institutional environments (cf. Ramamurti, 2009). Our findings suggest, however, that in certain circumstances, MNE 
political capabilities developed in institutionally different, more rule-governed home countries can provide firms with complementary transactional and organizational political capabilities, which in combination with newly acquired, relational capabilities allow them to develop effective CPA. Advanced country MNEs therefore possess a "prosperity advantage" when developing CPA for a relational context.

Yet, our framework also suggests that the value of transactional and certain types of organizational capabilities will decline when the institutional environment moves away from a rule-governed one towards a relationship-based one and when political risk becomes less predictable or discontinuous as is the case in a phase of "backsliding." This creates what we call the transferability-value dilemma, whereby transferable and hence easily available capabilities for subsidiaries are increasingly less valuable in relational environments characterized by discontinuous risk. We find that subsidiaries have to increasingly rely on locally developed personal relational capabilities to achieve external fit. However, this has implications for internal fit of the subsidiary strategy with capabilities that are shaped by a "rule-governed" home environment. Here, the dual challenge of internal and external fit increasingly becomes an obstacle to successful adaptation to the volatile environment. Therefore, our study also has implications for the theory of volatile institutional environments (Darendeli \& Hill, 2016; Oh \& Oetzel, 2017). It shows that up to a point, MNE subsidiaries are exceptionally well-equipped to deal with such environments due to their capability to mobilize different types of capabilities to formulate effective CPA. Yet, there may be a point where the environment may become too unpredictable for transactional and collective relational resources to have any value. This is where MNE subsidiaries may reach their limit of adaptability.

\subsection{Limitations and future research implications}


One limitation of our study is that it is based on an extreme case. This was a conscious choice, as such cases are particularly revealing of important empirical phenomena. However, this raises the issue of the boundary conditions of our findings. We would expect that our insights are applicable to other post-socialist countries that have recently experienced phases of "backsliding" (e.g. Russia and Poland), but they may also be relevant for other cases where discontinuous political risk is caused by the rise of authoritarian regimes. Future research should investigate in comparative fashion a wider range of such contexts.

Another limitation is that we did not distinguish differences in our MNEs subsidiaries home setting. This is because we limit our study to just one dimension of the national business system, namely the extent to which it is (formal) rule-governed or relationshipbased. We surmised that all Western countries included in our study are close to a fairly stable rule-governed system where the rule of law makes arm's length transactions possible (Chen \& Deakin, 2015; Peng 2003). Yet, even among advanced economies, some national models use relationships more extensively than others, although they differ in kind from the ones we observe in the case of Hungary (Hall \& Soskice, 2001; Peng, 2003). Nevertheless, MNE subsidiaries from more relationship-based countries may possess resources and capabilities that make them particularly successful in adapting to relationship-based systems in emerging markets (see Porter 1990 for the case of Italian companies in developing countries).

Our study also relates to the question of "institutional duality" (Kostova \& Roth, 2002). Previous research into institutional duality showed that MNEs can tap into capabilities from multiple local contexts and integrate them to create a range of competitive advantages (Kostova et al., 2008; Meyer et al., 2011; Regnér \& Edman, 2014; Saka-Helmhout et al., 2016). Our findings suggest that whether institutional duality is a resource or a constraint for an MNE may depend on whether the capabilities required in a specific host context are 
transferable or not. Future research should more systematically investigate the link between institutional duality and transferability of capabilities.

Beyond institutional factors, future research should also investigate firm-level factors that may explain different levels of adaptability in the face of discontinuous political risk and institutional upheaval. For instance, the existence of risk management or compliance departments within certain MNCs may have an impact on the leeway subsidiaries has to react to challenges in the host environment. ${ }^{2}$

\subsection{Managerial implications}

From a practitioner's point of view our study illustrates the importance of subsidiarylevel political strategy design and the role of subsidiaries' top management in this process. Our findings hint at the important tensions that emerge for foreign subsidiaries due to "backsliding." It indicates that developing relational capabilities of both the collective and increasingly personal type seems key to a successful political strategy in such contexts. However, it becomes also clear that faced with a government that increasingly disregards formal channels of interest representation, foreign companies may face delicate ethical questions in crafting effective CPA. Therefore, effective CPA should not be done by host country senior management or the subsidiary in insolation (as it is generally the case), but needs to be coordinated with the parent company. Two issues are particularly important for effective host-country CPA: First, the headquarters need to provide clear and effective guidelines about the limits of personal relational capabilities; Second, confidential and supportive communication channels between the subsidiaries top management and the headquarters are required to provide guidance on complex ethical decisions when dealing with host governments.

\footnotetext{
${ }^{2}$ We are grateful to an anonymous reviewer for pointing this out to us.
} 
Overall, the study of MNE subsidiary CPA can provide us with important insights into the ways in which competitive advantage can be created and maintained even in very challenging contexts. As the world is arguably entering a phase of more political instability, these lessons will be crucial for subsidiary survival. 


\section{References}

Bałtowski, M. \& Kozarzewski, P. 2016. 'Formal and real ownership structure of the Polish economy: state-owned versus state-controlled enterprises.' Post-Communist Economies. 28. $1-15$.

Barnard, H., 2010. Overcoming the liability of foreignness without strong firm capabilities the value of market-based resources. J. Int. Manag, 16:2, 165-176, https://doi.org/10.1016/j.intman.2010.03.007

Beyers, J. Eising, R. \& Maloney, W., 2008. Researching Interest Group Politics in Europe and Elsewhere: Much We Study, Little We Know?, West Eur. Politics, 31:6, 1103-1128, doi: $10.1080 / 01402380802370443$

Boddewyn, J.J., 2016. International business-government relations research 1945-2015: Concepts, typologies, theories and methodologies. J. World Bus. 51, 10-22. doi:10.1016/j.jwb.2015.08.009

Böhm, A, 2004. Theoretical Coding: Text Analysis in Grounded Theory. In Uwe Flick, Ernst von Kardoff, Ines Steinke (Eds). A Companion to Qualitative Research, 270-275. London, Sage Publications

Bonardi, J.-P., 2011. Corporate political resources and the resource-based view of the firm. Strateg. Organ. 9, 247-255. Doi: https://doi.org/10.1177/1476127011417926

Bonardi, J.-P., Holburn, G.L.F., Vanden Bergh, R.G., 2006. Nonmarket Strategy Performance: Evidence From U.S. Electric Utilities. Acad. Manag. J. 49, 1209-1228. https://doi.org/10.5465/AMJ.2006.23478676

Bremmer, I. 2008. The Return of State Capitalism. Survival: Global Politics and Strategy, 50(3), 55-64. https://doi.org/10.1080/00396330802173198

Brouthers, L.E., Brouthers, K.D., Werner, S., 2000. Perceived Environmental Uncertainty, Entry Mode Choice and Satisfaction with EC-MNC Performance. Br. J. Manag. 11, 183- 
195. https://doi.org/10.1111/1467-8551.00160

Bryman, A. 2004. Social Research Methods. Oxford University Press, Oxford.

Carney, M., Dieleman, M., Taussig, M., 2016. How are institutional capabilities transferred across borders? J. World Bus. 51, 882-894. doi:10.1016/j.jwb.2015.12.002

Chen, D., Deakin, S., 2015. On Heaven's Lathe: State, Rule of Law, and Economic Development. Law Dev. Rev. 8, 123-145. https://doi.org/10.1515/ldr-2014-0031

Chen, R., Cui, L., Li, S., \& Rolfe, R. 2017. Acquisition or greenfiled entry inot Africa? Responding to institutional dynamics in an emerging continent. G. Strat. J., (7), 212-230. https://doi.org/10.1002/gsj

Child, J., Rodrigues, S.B., Tse, K.K.-T., 2012. The Dynamics of Influence in Corporate CoEvolution. J. Manag. Stud. 49, 1246-1273. doi:10.1111/j.1467-6486.2012.01057.x

Cuervo-Cazurra, A., 2008. Better the devil you don't know: Types of corruption and FDI in transition economies. J. Int. Manag. 14, 12-27. https://doi.org/10.1016/j.intman.2007.02.003

Danisz, W.M., Chiaburu, D.S., Lyles, M.A., 2010. The impact of managerial networking intensity and market-based strategies on firm growth during institutional upheaval: A study of small and medium-sized enterprises in a transition economy. J. Int. Bus. Stud. 41, 287-307. doi:10.1057/jibs.2009.45

Darendeli, I.S., Hill, T.L., 2016. Uncovering the complex relationships between political risk and MNE firm legitimacy: Insights from Libya. J. Int. Bus. Stud. 47, 68-92. https://doi.org/10.1057/jibs.2015.27

Delios, A. and Henisz, W.J. 2003. Political hazards, experience, and sequential entry strategies: the international expansion of Japanese firms, 1980-1998. Strat. Mgmt. J., 24: 1153-1164. doi:10.1002/smj.355 
Deng, Z., Yan, J., \& van Essen, M. 2018. Heterogeneity of political connections and outward foreign direct investment. Int. Bus. Rev., 27(4), 893-903. https://doi.org/10.1016/j.ibusrev.2018.02.001

Dieleman, M., Boddewyn, J.J., 2012. Using Organization Structure to Buffer Political Ties in Emerging Markets : A Case Study. Orga 33, 71-95. doi:10.1177/0170840611430595

Dieleman, M., Sachs, W.M., 2008. Coevolution of Institutions and Corporations in Emerging Economies: How the Salim Group Morphed into an Institution of Suharto's Crony Regime. J. Manag. Stud. 45, 1274-1300., doi: |https://doi.org/10.1111/j.14676486.2008.00793.x

Dieleman, M., \& Widjaja, H. 2019. How powerful political ties appropriate resources and how weaker organizations protect themselves: A case study from Indonesia. Asia Pac. J. Man., 36(1), 61-86. https://doi.org/10.1007/s10490-018-9563-2

Doh, J.P., Lawton, T.C., Rajwani, T., 2012. Advancing Nonmarket Strategy Research: Institutional Perspectives in a Changing World. Acad. Manag. Perspect. 26, 22-39., doi: https://doi.org/10.5465/amp.2012.0041

Dunning, J.H., Lundan, S.M., 2010. The institutional origins of dynamic capabilities in multinational enterprises. Ind. Corp. Chang. 19, 1225-1246. https://doi.org/10.1093/icc/dtq029

EBRD, 2005. Transition report 2005: Business in transition London. Transit. Rep.

Edwards, T., Schnyder, G., Fortwengel, J., 2019. Mapping the impact of home- and hostcountry institutions on human resource management in emerging market multinational companies: A conceptual framework. Thunderbird Int. Bus. Rev. 61, 531-544. https://doi.org/10.1002/tie.22036

Edwards, T., Sanchez-Mangas, R., Bélanger, J., Mcdonnell, A., 2015. Why are some 
subsidiaries of multinationals the source of novel practices while others are not? National, corporate and functional influences. Br. J. Manag. 26, 146-162. https://doi.org/10.1111/1467-8551.12090

Edwards, T., Rees, C., Coller, X., 1999. Structure, Politics and the Diffusion of Employment Practices in Multinationals. Eur. J. Ind. Relations 5, 286-306.

Eisenhardt, K. 1989. Building Theories from Case Study Research. Acad. Man. Rev., 14 (4), 532-550. www.jstor.org/stable/258557

Estrin, S., Meyer, K. E., \& Pelletier, A. 2018. Emerging Economy MNEs: How does home country munificence matter? J. World Bus., 53(02), 514-528. https://doi.org/10.1016/j.jwb.2018.02.004

Estrin, S., Nielsen, B. B., Nielsen, S. 2017. Emerging Market Multinational Companies and Internationalization: The Role of Home Country Urbanization, J. Int. Man., 23, 326-339

Fainshmidt, Stav \& Pezeshkan, Amir \& Frazier, M \& Nair, Anil \& Markowski, Edward. 2016. Dynamic Capabilities and Organizational Performance: A Meta-Analytic Evaluation and Extension. J. of Man. Stud. 53. 10.1111/joms.12213.

Feinberg, S., Hill, T.L., Darendeli, I.S., 2015. An institutional perspective on non-market strategies for a world in flux, in: Lawton, T.C., Rajwani, T.S. (Eds.), The Routledge Companion to Non-Market Strategy. Routledge, London, pp. 29-45.

Fernández-Méndez, L., García-Canal, E., \& Guillén, M. F. 2018. Domestic political connections and international expansion: It's not only 'who you know' that matters. J. World Bus., 53(5), 695-711. https://doi.org/10.1016/j.jwb.2018.03.006

Ferner, A., Edwards, T., Tempel, A., 2012. Power, institutions and the crossnational transfer of employment practices in multinationals. Hum. Relations 65, 163-187. https://doi.org/10.1177/0018726711429494 
Flynn, B.B., Kakibara, S.S., Schroeder, R.G., Bates, K.A., Flynn, E.J., 1990. Empirical Research Methods in Operations Management. J. Oper. Manag. 9, 250-284., doi: https://doi.org/10.1016/0272-6963(90)90098-X

Fortwengel, J. 2017a. Practice Transfer in Organizations: The Role of Governance Mode for Internal and External Fit. Org. Sci., 28(4), 690-710.

Fortwengel, J. 2017b. Understanding When MNCs can Overcome Institutional Distance : A Research Agenda. Man. Int. Rev., 57(6), 793-814. https://doi.org/10.1007/s11575-0170327-x

Fukuyama, F. 1995. Trust: The social virtues and the creation of prosperity. New York: The Free Press.

Frynas, J.G., Mellahi, K., Pigman, G.A., 2006. First Mover Advantages in International Business and Firm-Specific Political Resources. Strateg. Manag. J. 27, 321-345. doi:10.1002/smj.519

Gamble, J., 2010. Transferring organizational practices and the dynamics of hybridization: Japanese retail multinationals in China. J. Manag. Stud. 47, 705-732. https://doi.org/10.1111/j.1467-6486.2009.00876.x

Getz, K.A., Oetzel, J., 2009. MNE strategic intervention in violent conflict: Variations based on conflict characteristics. J. Bus. Ethics 89, 375-386. https://doi.org/10.1007/s10551010-0412-6

Greskovits, Béla, 2015. The Hollowing and Backsliding of Democracy in East Central Europe. Global Policy, 6, 1, https://doi.org/10.1111/1758-5899.12225

Griffin, J.J., Dunn, P., 2004. Corporate Public Affairs: Commitment, Resources, and Structure. Bus. Soc. 43, 196-220. doi:10.1177/0007650304266277

Hadjikhani, A., \& Ghauri, P. N. 2006. Multinational Enterprises and Their Lobbying Activities in the European Union. In L. Oxelheim (Ed.), Corporate and Institutional 
Transparency for Economic Growth in Europe. Amsterdam: Elsevier.

Hall PA, Soskice D. 2001. Varieties of Capitalism: The Institutional Foundations of Comparative Advantage. Oxford University Press, Oxford.

Hamilton, G. G. 1996. Asian Business Networks. Walter de Gruyter, Berlin.

Harsányi, F.M., Schmidt, S., 2012. Creating a public affairs function in countries without a public affairs culture. J. Public Aff. 12, 86-97. doi: |https://doi.org/10.1002/pa.407

Henisz, W., Delios, A., 2004. Information or influence? The benefits of experience for managing political uncertainty. Strateg. Organ. 2, 389-421. doi:10.1177/1476127004047619

Hillman, A.J., Hitt, M.A., 1999. Corporate Political Strategy Formulation : A Model of Approach, Participation, and Strategy. Acad. Manag. Rev. 24, 825-842. doi:10.1093/afraf/adil23

Hillman, A.J., Wan, W.P., 2005. The determinants of MNE subsidiaries' political strategies: evidence of institutional duality. J. Int. Bus. Stud. 36, 322-340. doi:10.1057/palgrave.jibs. 8400137

Hitt, M. A., Lee, H.-U., \& Yucel, E. 2002. The Importance of Social Capital to the Management of Multinational Enterprises : Relational Networks. Asia Pac. J. Manage., $19,353-372$.

Holbourn \& Zelner, 2010. Political capabilities, policy risk, and international investment strategy: evidence from the global electric power generation industry. Strat. Mgmt. J., 31: 1290-1315, doi: $10.1002 / \mathrm{smj} .860$

Iankova, E., Katz, J., 2003. Strategies for political risk mediation by international firms in transition economies: the case of Bulgaria. J. World Bus. 38, 182-203. doi:10.1016/S1090-9516(03)00018-X

Jean, R. J. “Bryan,” \& Tan, D. 2019. The Effect of Institutional Capabilities on E-Business 
Firms’ International Performance. Man. Int. Rev., 59(4), 593-616.

https://doi.org/10.1007/s11575-019-00389-4

Jensen, R., Szulanski, G., 2004. Stickiness and the adaptation of organizational practices in cross-border knowledge transfers. J. Int. Bus. Stud. 35, 508-523.

doi:10.1057/palgrave.jibs. 8400107

Judge, W. 2012. Relation-based Versus Rule-Based Governance Systems. Corporate Governance: An International Review, 20, 411-412. doi:10.1111/j.14678683.2012.00929.x

King, B.G., Pearce, N.A., 2010. The contentiousness of markets: Politics, social movements, and institutional change in markets. Annu. Rev. Sociol. 36, 249-67. doi:10.1146/annurev.soc.012809.102606

Kline, A. W., Brown, S. R., 2019. Overcoming the Liability of Foreignness through Lobbying: an Examination of Franchise Systems, J. Int. Man., 25, 1-14

Konara, P., Shirodkar, V., 2018. Regulatory Institutional Distance and MNCs' Subsidiary Performance: Climbing up Vs. Climbing Down the Institutional Ladder, J. Int. Man., 24, $333-347$

Kostova, T., Roth, K., Dacin, M.T., 2008. Institutional Theory in the Study of Multinational Corporations: A Critique and New Directions. Acad. Manag. Rev. 33, 994-1006. https://doi.org/10.5465/AMR.2008.34422026

Kostova, T., Roth, K., 2002. Adoption of an organizational practice by subsidiaries of multinational corporations: Institutional and relational effects. Acad. Manag. J. 45, 215233. doi: $10.2307 / 3069293$

Kostova, T., 1999. Transnational Transfer of Strategic Organizational Practices: A Contextual Perspective. Acad. Manag. Rev., 24, 308-324. https://doi.org/10.5465/amr.1999.1893938 Kostova, T., Zaheer, S., 1999. Organizational Legitimacy under Conditions of Complexity : 
The Case of the Multinational Enterprise. Acad. Manag. Rev. 24, 64-81., https://www.jstor.org/stable/259037

Kotabe, Masaaki \& Xiangwen Jiang, Crystal \& Y. Murray, Janet. 2011. Managerial Ties, Knowledge Acquisition, Realized Absorptive Capacity and New Product Market Performance of Emerging Multinational Companies: A Case of China. J. of World Bus. 46. 166-176. 10.1016/j.jwb.2010.05.005.

Lawton, T., Mcguire, S., Rajwani, T., 2013. Corporate Political Activity: A Literature Review and Research Agenda. Int. J. Manag. Rev. 15, 86-105. doi:10.1111/j.14682370.2012.00337.x

Leuz, C., Oberholzer-Gee, F., 2006. Political relationships, global financing, and corporate transparency: Evidence from Indonesia. J. Financ. Econ. 81, 411-439. doi:10.1016/j.jfineco.2005.06.006

Levitsky, S., \& Murillo, V. 2009. Variation in Institutional Strength. Annu. Rev. Polit. Sci., 12, 115-133. https://doi.org/10.1146/annurev.polisci.11.091106.121756

Liedong, T.A., Ghobadian, A., Rajwani, T., O’Regan, N., 2015. Toward a View of Complementarity: Trust and Policy Influence Effects of Corporate Social Responsibility and Corporate Political Activity. Gr. Organ. Manag. 40, 405-427. https://doi.org/10.1177/1059601114560064

Luo, Y., 2007. From foreign investors to strategic insiders: Shifting parameters, prescriptions and paradigms for MNCs in China. J. World Bus. 42, 14-34. doi:10.1016/j.jwb.2006.08.009

Luo, Y., Park, S.H.O., 2001. Strategic Alignment and Performance of Market-Seeking MNCs in China. Strateg. Manag. J. 22, 141-155.

Luo, Y., Zhao, H., 2013. Doing Business in a Transitional Society: Economic Environment and Relational Political Strategy for Multinationals. Bus. Soc. 52, 515-549. 
doi:10.1177/0007650309338365

Lux, S., Crook, T.R., Woehr, D.J., 2011. Mixing Business with Politics: A Meta-Analysis of the Antecedents and Outcomes of Corporate Political Activity. J. Manage. 37, 223-247. doi:10.1177/0149206310392233

Mbalyoherea, C., Lawton, T., 2018. Engaging Stakeholders Through Corporate Political Activity: Insights From MNE Nonmarket Strategy in an Emerging African Market, J. Int. Man., 24, 369-385, doi: https://doi.org/10.1016/j.intman.2018.04.006

McDonnell, M.-H., Werner, T., 2016. Blacklisted Businesses Social Activists' Challenges and the Disruption of Corporate Political Activity. Adm. Sci. Q. 1839216648953. doi:10.1177/0001839216648953

McGrath, C., 2005. Towards a lobbying profession: developing the industry's reputation, education and representation. J. Public Aff. 5, 124-135. doi:10.1002/pa.14

Meyer, K.E., Mudambi, R., Narula, R., 2011. Multinational Enterprises and Local Contexts: The Opportunities and Challenges of Klaus E. Meyer, Ram Mudambi and Rajneesh Narula. J. Manag. Stud. 48, 235-252. doi:10.1111/j.1467-6486.2010.00968.x

Meyer, K.E., Peng, M.W., 2016. Theoretical foundations of emerging economy business research. J. Int. Bus. Stud. 47, 3-22. doi:10.1057/jibs.2015.34

Miles, M. B. \& Huberman, M. A. 1994. Qualitative Data Analysis: An expanded sourcebook, Thousand Oaks: Sage.

Mingo, S., Junkunc, M., \& Morales, F. 2018. The interplay between home and host country institutions in an emerging market context: Private equity in Latin America. J. World Bus., 53(5), 653-667. https://doi.org/10.1016/j.jwb.2018.03.005

Levitsky, S. \& Murillo M. V., 2009. Variation in Institutional Strength. Annual Review of Political Science 2009 12:1, 115-133

Nell, P.C., Puck, J., Heidenreich, S., 2015. Strictly limited choice or agency? Institutional 
duality, legitimacy, and subsidiaries ' political strategies. J. World Bus. 50, 302-311.

Nölke, A. 2018. Dependent versus state-permeated capitalism : two basic options for emerging markets. Int. J. Manage. Econ., 54(4), 269-282.

North, D. C. 1990. Institutions, Institutional Change and Economic Performance. Cambridge University Press, Cambridge.

Oetzel, J. M., \& Miklian, J. 2017. Multinational enterprises, risk management, and the business and economics of peace. Mult. Bus. Rev., 25(4), 270-286. https://doi.org/10.1108/MBR-09-2017-0064

Oetzel, J.M., \& Oh, C.H., 2014. Learning to Carry the Cat by the Tail: Firm Experience, Disasters, and Multinational Subsidiary Entry and Expansion. Organ. Sci. 25, 732-756. https://doi.org/10.1287/orsc.2013.0860

Oh, C.H., \& Oetzel, J.M., 2011. Multinationals’ Response to Major Disasters: How does subsidiary investment vary in response to the type of disaster and the quality of country governance? Strateg. Manag. J. 681, 658-681. https://doi.org/10.1002/smj

Oh, C.H., \& Oetzel, J.M., 2017. Once Bitten Twice Shy? Experience managing violent conflict risk and MNC subsidiary-level investment and expansion. Strateg. Manag. J. 38, 714-731. https://doi.org/10.1002/smj

Oliver, C., \& Holzinger, I., 2008. The Effectiveness of Strategic Political Management: A Dynamic Capabilities Framework. Acad. Manag. Rev. 33, 496-520., http://www.jstor.org/stable/20159410

Orenstein, M.A., 2013. Reassessing the neo-liberal development model in Central and Eastern Europe, in: Resilient Liberalism in Europe's Political Economy. Cambridge University Press, Cambridge, pp. 374-402.

Peng, M.W., 2003. Institutional Transitions and Strategic Choices. Acad. Manag. Rev. 28, 275-296., https://doi.org/10.5465/amr.2003.9416341 
Perkins, S.E., 2014. When Does Prior Experience Pay? Institutional Experience and the Multinational Corporation. Adm. Sci. Q. 59, 145-181.

https://doi.org/10.1177/0001839214523603

Perry, C., 1998. Processes of a case study methodology for postgraduate research in marketing. Eur. J. Mark. 39, 785-802., https://doi.org/10.1108/03090569810232237

Porter, M. 1990. The Competitive Advantage of Nations. New York: Free Press.

Qi, G., Zou, H., Xie, X., Meng, X., Fan, T., \& Cao, Y. 2018. Obedience or escape: Examining the contingency influences of corruption on firm exports. J. Bus. Res., (09). https://doi.org/10.1016/j.jbusres.2018.09.004

Ramamurti, R., 2009. What have we learned about emerging market MNEs?, in: Ramamurti, R., Singh, J. V. (Eds.), Emerging Multinationals in Emerging Markets. Cambridge University Press, Cambridge, pp. 399-426.

Redding, S. G. 1990. The Spirit of Chinese Capitalism. Berlin: Walter de Gruyter.

Regnér, P., Edman, J., 2014. MNE institutional advantage : How subunits shape, transpose and evade host country institutions. J. Int. Bus. Stud. 45, 275-302. doi:10.1057/jibs.2013.66

Ren, M., Manning, S., Vavilov, S., 2019. Does state ownership really matter? The dynamic alignment of China's resource environment and firm internationalization strategies, J. Int. Man., 25, 1-17

Rui, H., Zhang, M., \& Shipman, A. 2017. Chinese expatriate management in emerging markets: A competitive advantage perspective. J. Int. Man., 23(2), 124-138. https://doi.org/10.1016/j.intman.2017.01.002

Saka-Helmhout, A., Deeg, R., Greenwood, R., 2016. The MNE as a Challenge to Institutional Theory: Key Concepts, Recent Developments and Empirical Evidence. J. Manag. Stud. 53, 1-11. doi:10.1111/joms.12172 
Sallai, D., 2013. European Union Lobbying and the Golden Cage of Post-Socialist Network Capitalism in Hungary. J. Common Mark. Stud. 51, 948-964. doi:10.1111/jems.12029 Sallai, D., Schnyder, G., 2015. Strong State, Weak Managers : How Hungarian firms cope with autocracy 1-27, Centre for Business Research, University of Cambridge Working Paper no. 474, https://ideas.repec.org/p/cbr/cbrwps/wp474.html

Sallai, D. and Schnyder, G., (forthcoming) What is "Authoritarian" about Authoritarian Capitalism? The dual erosion of the private-public divide in state-dominated business systems.” Bus. \& Soc. (available at: SSRN: https://ssrn.com/abstract=3373637)

Santos, Felipe M., Kathleen M. Eisenhardt., 2009. Constructing Markets and Shaping Boundaries: Entrepreneurial Power in Nascent Fields. Acad. of Man. J., 52, 4, 2009, pp. 643-671. www.jstor.org/stable/40390310.

Sedelmeier, U., 2014. Anchoring Democracy from Above? The European Union and Democratic Backsliding in Hungary and Romania after Accession. J. Common Mark. Stud. 52, 105-121. https://doi.org/10.1111/jcms. 12082

Siegel, J., 2007. Contingent Political Capital and International Alliances : Evidence from South Korea. Adm. Sci. Q. 52, 621-666. doi:10.2189/asqu.52.4.621

Stark, D., Bruszt, L., 1998. Postsocialist Pathways: transforming politics and property in East Central Europe. Cambridge University Press, Cambridge.

Sun, P., Mellahi, K., Thun, E., 2010. The dynamic value of MNE political embeddedness: The case of the Chinese automobile industry. J. Int. Bus. Stud. 41, 1161-1182. doi:10.1057/jibs.2009.94

Sun, P., Mellahi, K., Wright, M., Xu, H., 2015. Political Tie Heterogeneity and the Impact of Adverse Shocks on Firm Value. J. Manag. Stud. 52, 1036-1063. doi:10.1111/joms.12165 Szanyi, M. 2016. 'The Reversal of the Privatisation Logic in Central European Transition Economies (An Essay).' Acta Oeconomica. 66. 33-55. 
Szulanski, G., 1996. Exploring internal stickiness: Impediments to the transfer of best practice within the firm. Strateg. Manag. J. 17, 27-43. doi:10.1002/smj.4250171105

Teece, D.J., Pisano, G., Shuen, A., 1997. Dynamic Capabilities and Strategic Management. Strateg. Manag. J. 18, 509-533., doi: https://doi.org/10.1002/(SICI)10970266(199708)18:7\%3C509::AID-SMJ882\%3E3.0.CO;2-Z

Thomson, S. and S. John, 2007. Public Affairs in Practice - A practical guide to lobbying. London, Kogan Page Ltd.

Tsui-Auch, Lai Si, Chow, Dawn, 2019. MNEs' Agency Within Institutional Contexts: A Study of Walmart's Post-acquisition Practices in Mexico, Germany, and Japan, J. of Int. Man. 25, 2, 1-16

Van Schendelen, R., 2012. New trends of public affairs management at the EU level. J. Public Aff. 12, 39-46. doi:10.1002/pa.380

Voinea, C. L., \& van Kranenburg, H. 2018. Feeling the Squeeze: Nonmarket Institutional Pressures and Firm Nonmarket Strategies. Man. Int. Rev. (Vol. 58). https://doi.org/10.1007/s11575-018-0355-1

Walker, C. \& Habdank-Kolaczkowska, S. 2012. Nations in Transit - Fragile frontier: Democracies growing vulnerability in Central and Southeastern Europe. Freedomhouse available at: https://www.freedomhouse.org/sites/default/files/Release\%20Booklet.pdf.

Weimer, J., \& Pape, J. C. 1999. A Taxonomy of Systems of Corporate Governance. Corp. Gov. Int. Rev., 7(2), 152-166.

Witt, M. A., \& Redding, G., 2013. Asian Business Systems: Institutional Comparison, Clusters, and Implications for Varieties of Capitalism and Business Systems Theory. SocioEconomic Review, 11, 2, 265-300. 
White, G.O., Fainshmidt, S., Rajwani, T., 2018a. Antecedents and Outcomes of Political Tie Intensity: Institutional and Strategic Fit Perspectives. J. Int. Manag. 24, 1-15. https://doi.org/10.1016/j.intman.2017.06.001

White, G. O., Hemphill, T., Weber, T., \& Moghaddam, K. 2018b. Institutional origins of WOFS formal contracting: A judicial arbitrariness perspective. Int. Bus. Rev., 27(3), 654-668. https://doi.org/10.1016/j.ibusrev.2017.11.002

Whitley, R., 2007. Business Systems and Organizational Capabilities. Oxford University Press, Oxford.

Whitley, R., Henderson, J., Czaban, L., Lengyel, G., 1996. Trust and Contractual Relations in an Emerging Capitalist Economy: The Changing Trading Relationships of Ten Large Hungarian Enterprises. Organization Studies, 17(3), 397-420., doi: https://doi.org/10.1177/017084069601700303

Witt, M.A., Kabbach de Castro, L.R., Amaeshi, K., Mahroum, S., Bohle, D., Saez, L., 2017. Mapping the business systems of 61 major economies. Socio-Economic Rev. 0, 1-34. https://doi.org/10.1093/ser/mwx012

Wood, G., \& Wright, M. 2015. Corporations and New Statism: Trends and Research Priorities. Acad. of Man. Persp., 29(2), 271-286.

Yan, Z. J., Zhu, J. C., Fan, D., \& Kalfadellis, P. 2018. An institutional work view toward the internationalization of emerging market firms. J. World Bus., 03, 0-1. https://doi.org/10.1016/j.jwb.2018.03.008

Yin, R. 2003. Case study research: Design and methods. Thousand Oaks: Sage.

Young, M., Peng, M. W., Ahlstrom, D., Bruton, G. D., 2003. Principal-Principal Agency.

Chin. Man. Rev., 6, 1, 18-45, available at

http://cmr.ba.ouhk.edu.hk/cmr/webjournal/v6n1/webj06-02.pdf

Young, M., Peng, M.W., Ahlstrom, D., Bruton, G.D., Jiang, Y., 2008. Corporate governance 
in emerging economies: A review of the principal-principal perspective: Review paper. J.

Manag. Stud. 45, 196-220., doi:10.1111/j.1467-6486.2007.00752.x

Yu, J., \& Lee, S. H. 2019. Bending the Rules or Changing Them? MNE Responses to Institutional Challenges in Transition Economies. Bus. Soc. https://doi.org/10.1177/0007650319843805

Zajac, E.J., Kraatz, M.S., Bresser', R.K.F., 2000. Modeling the Dynamics of Strategic Fit: A normative approach to strategic change. Strateg. Manag. J. 21, 429-453.

Zhang, Y., Zhao, W., Ge, J., 2016. Institutional duality and political strategies of foreigninvested firms in an emerging economy. J. World Bus. 51, 451-462. doi:10.1016/j.jwb.2015.12.004

Zyglidopoulos, S., Dieleman, M., \& Hirsch, P. 2019. Playing the Game: Unpacking the Rationale for Organizational Corruption in MNCs. J. Man. Inq. https://doi.org/10.1177/1056492618817827 